\title{
The global pipeline of new medicines for the control and elimination of malaria
}

\author{
Melinda P Anthony, Jeremy N Burrows, Stephan Duparc, Joerg JMoehrle and Timothy NC Wells*
}

\begin{abstract}
Over the past decade, there has been a transformation in the portfolio of medicines to combat malaria. New fixed-dose artemisinin combination therapy is available, with four different types having received approval from Stringent Regulatory Authorities or the World Health Organization (WHO). However, there is still scope for improvement. The Malaria Eradication Research agenda identified several gaps in the current portfolio. Simpler regimens, such as a single-dose cure are needed, compared with the current three-day treatment. In addition, new medicines that prevent transmission and also relapse are needed, but with better safety profiles than current medicines. There is also a big opportunity for new medicines to prevent reinfection and to provide chemoprotection. This study reviews the global portfolio of new medicines in development against malaria, as of the summer of 2012. Cell-based phenotypic screening, and 'fast followers' of clinically validated classes, mean that there are now many new classes of molecules starting in clinical development, especially for the blood stages of malaria. There remain significant gaps for medicines blocking transmission, preventing relapse, and long-duration molecules for chemoprotection. The nascent pipeline of new medicines is significantly stronger than five years ago. However, there are still risks ahead in clinical development and sustainable funding of clinical studies is vital if this early promise is going to be delivered.
\end{abstract}

Keywords: Drugs, Resistance, Combinations, ACT, Endoperoxide, Spiroindolone, Relapse, Transmission

\section{Background}

Recent years have seen a transformation in the landscape of malaria drug discovery and development. A review of publicly available data from PubMed, clinicaltrials.gov as well as proprietary databases, such as Thomson Pharma, revealed that as of March 2012, over 50 projects were in progress worldwide. These include a wide variety of molecules in the window between late discovery (within 12 months of starting regulatory preclinical studies) and launch. Twenty-seven of these are in formal regulatory studies and beyond. In addition, in the past three years, five new medicines have either been approved by Stringent Regulatory Authorities [those that adhere to the guidelines of the International Commission for Harmonisation ( $\mathrm{ICH})$, or prequalified by the World Health Organization (WHO)].

\footnotetext{
* Correspondence: wellst@mmv.org

Medicines for Malaria Venture (MMV), 20 rte de Pré-Bois 1215, Geneva, Switzerland
}

The portfolio of new medicines contains several generations of products. The oldest group reflects the requirement for fixed-dose, artemisinin-combination therapy (ACT), driven by the need to protect artemisinin from the emergence and spread of resistance. This therapy is based around active molecules that were first identified over 30 years ago. The central focus for the development process of this therapy has been ensuring that the historical data available match current international standards of safety and efficacy.

The call for the eradication of malaria in 2007 led to a new research agenda [1] laying out priorities with broader horizons. As well as the focus on case management of uncomplicated and severe malaria, there is now a need for medicines that prevent transmission, stop relapse and provide chemoprotection against new infections. These characteristics are described by Target Product Profiles (TPPs), which give a description of the ideal medicine and the minimum acceptable profile. TPPs provide drug discoverers with a common standard of the unmet clinical needs in malaria control and

\section{Biomed Central}


eradication, thereby allowing a better focus. TPPs were developed with input from countries, field-based clinicians, and discovery and development teams [2], and are refined every two years [3].

\section{Methodology}

This review aims to be as complete as possible, and not simply to be a review of projects supported by Medicines for Malaria Venture (MMV). To obtain such a global view, the data were obtained from publicly available sources, such as Medline, clinicaltrials.gov, and company websites, supported by commercial databases, such as Thomson Pharma (www.thomson-pharma.com). There is unfortunately insufficient space to cite every single source. The data were updated in March-April 2012, although it is appreciated that the picture is continually evolving.

\section{Controlling malaria: artemisinin combination therapy as first-line treatment}

Today, first-line medicines against malaria are fixeddose artemisinin combination therapy (ACT). These medicines are assumed to be active against the blood stages of all of the major forms of Plasmodium which infect humans: falciparum, vivax, malariae, ovale and knowlesi. Fixed-dose combination therapy has the advantage over co-blistered presentations in that it eliminates the potential for monotherapy [4], which is to be avoided since it risks the emergence and selection of resistant parasites [5]. Six of these have been reviewed by regulatory authorities throughout the world (see Table 1, Figures 1 and 2). Artemether-lumefantrine (Coartem $^{\circledR}$ and Coartem ${ }^{\circledR}$ Dispersible from Novartis), artesunate-amodiaquine (Coarsucam ${ }^{\mathrm{Tm}} /$ Artesunate Amodiaquine-Winthrop $^{\circledR}$ from Sanofi), pyronaridine-artesunate (Pyramax ${ }^{\circledR}$ from Shin Poong Pharmaceuticals) and mefloquine-artesunate from Cipla/DNDi- have been prequalified by WHO [6]. Their launch has had a dramatic impact on the number of courses of treatment available to malaria patients. There has been rapid growth from 62.3 million treatments in 2006 to 159.7 million in 2010 (see Figure 2) although, still, not all medicines reach the patients who need them [7]. Considerable progress has been made on price, with the costs of an adult course of treatment falling to $\$ 1.00-\$ 1.40$. For infants the price can be as low as $\$ 0.30$ [8], although in 2011 prices rose due to perceived artemisinin shortages [9].

The two major artemisinin combination therapies are:

(a) Artemether-lumefantrine $\left(\right.$ Coartem $^{\circledR}$ and the dispersible paediatric formulation Coartem $^{\circledR}$ Dispersible from Novartis). Over 500 million treatments of these medicines have been delivered since the initial launch in 2002, of which over 100 million are now the dispersible form specifically designed for children. Several generic versions of this medicine have now been produced, including those prequalified by WHO.

(b) Amodiaquine-artesunate Coarsucam $^{\mathrm{Tm}}$ and Artesunate Amodiaquine Winthrop ${ }^{\circledR}$, from Sanofi). This was initially approved in Morocco, where it is manufactured and was prequalified by $\mathrm{WHO}$ in 2008.

There are four other types of ACT prescribed for the treatment of uncomplicated malaria, which are currently at different stages of registration and approval.

(a) Dihydroartemisinin (DHA)-piperaquine (Eurartesim $^{\circledR}$ from Sigma-tau) was approved by the European Medicines Agency (EMA) in October 2011 [43] and is included in the Malaria Treatment Guidelines this year [44]. New data showing twoyear stability are now available. Prequalification by WHO and submission in key disease-endemic countries is expected in 2012. Holley-Cotec produce another version of DHA-piperaquine (DuoCotecxin ${ }^{\circledR}$ ) [45], available in many countries, which is expected to be submitted soon for prequalification.

(b) Pyronaridine-artesunate (Pyramax ${ }^{\circledR}$ from Shin Poong Pharmaceuticals) was approved by the Korean Food \& Drugs Administration (KFDA) in August 2011 [46], and was approved by the EMA in February 2012, under Article 58 [47], where opinion is given on whether a medicine is suitable for use in countries where the disease is endemic. This avoids the obligation to market the medicine in Europe, and is a decision made in conjunction with WHO, which has now prequalified the product.

(c) Artesunate-mefloquine (ASMQ) is a fixed-dose combination produced by Cephalon/Mepha as a paediatric formulation for commercial markets in Africa, and by the Drugs for Neglected Diseases initiative (DND $i$ ) in partnership with Farmanguinhos for use in Brazil. From 2012, the fixed-dose combination will be manufactured and registered by Cipla in India, which will accelerate uptake [48]. WHO prequalification was obtained in September 2012. Currently the market price of mefloquine (over $\$ 1,000 / \mathrm{kg}$ ) makes this combination the most expensive $\mathrm{ACT}$, however work is ongoing to lower the cost of manufacturing. A cheaper synthesis of mefloquine has been developed by Development Chemicals in collaboration with DND $i$ and MMV. This allows a price similar to other fixed-dose ACT.

(d) Artemisinin-naphthoquine $\left(\mathrm{ARCO}^{\circledR}\right.$, Kunming, China) is available in Africa as a one-day treatment. There are relatively few data available on the 
Table 1 Fixed-dose artemisinin combination therapy approved or in development (as of November 2011)

\begin{tabular}{lllll}
\hline Active ingredients & Partnership & Phase/status & Product name(s) & Comments
\end{tabular}

Coarsucam $^{\circledR}$ amodiaquine $(270 \mathrm{mg}) \times 2$ q.d.

Dihydroartemisinin $(40 \mathrm{mg})$ piperaquine $(320 \mathrm{mg}) \times 3$ g.d. sigma-tau, MMV,

Chongqing Holley Holding
Approved

\section{Coartem ${ }^{\circledR} ;$}

Coartem ${ }^{\circledR}$-Dispersible

\section{Coartem was launched in 2001}

Coartem Dispersible is a

specific paediatric formulation

with a sweet-tasting flavour.

It is given twice per day for

three days. Coartem Dispersible decreases

gametocytes by $6-8$ - fold compared

to sulphadoxine/pyrimethamine and

chloroquine. Approved by Swissmedic

in Dec 2008, it received WHO prequalification

in Feb 2009. Four dose strengths are

registered in 83 countries. In Apr 2009

Novartis received approval from the

'Priority Review Voucher' (PRV).

Marketed as Coarsucam in the private market and ASAQ-Winthrop in the

public markets. Given once per day for

three days. Originally registered in

Morocco, it is now approved in 31

countries (including 25 in Africa)

and prequalified in 2008 by WHO, but

so far has not been submitted to a

Stringent Regulatory Authority.

Stability data now available for

three years in Zone $\mathrm{IVb}\left(30^{\circ} \mathrm{C}\right.$

and $75 \%$ relative humidity),

compared to two years for

other ACT.

Available as Duo-Cotexcin since 2005

(approved by Sino-FDA), uses the

active metabolite of artemisinin,

dihydroartemisinin. Given once

per day for three days. Two pivotal

clinical trials led to approval by the

EMA in 2011. Prequalification

expected 2012. Shows superiority

to artemether-lumefantrine in

post-treatment protection until day 63 .

Approved by the Korean K-FDA, and by

the EMA, article 58 in Feb 2012.

Prequalified by WHO. Given once

per day for three days. Four pivota

clinical studies were performed 2007-2009,

with the first regulatory studies on an ACT

in both Plasmodium falciparum and

Plasmodium vivax malaria. Shows superiority

Chemical References

structure

in Figure 1

a), f)

[10-17]


Table 1 Fixed-dose artemisinin combination therapy approved or in development (as of November 2011) (Continued)

\begin{tabular}{|c|c|c|c|c|c|c|}
\hline & & & & $\begin{array}{l}\text { to artemether-lumefantrine in post-treatment } \\
\text { protection until day } 42 \text {. }\end{array}$ & & \\
\hline $\begin{array}{l}\text { Mefloquine, }(200 \mathrm{mg}), \\
\text { artesunate }(100 \mathrm{mg}), \times 2 \text { qd }\end{array}$ & $\begin{array}{l}\text { Farmanguinhos, DNDi, } \\
\text { (Cipla Ltd, MMV), } \\
\text { Mepha Ltd }\end{array}$ & $\begin{array}{l}\text { Launched (Brazil) 2008; } \\
\text { Launched (Portugal) } 2003\end{array}$ & ASMQ; Artequin & $\begin{array}{l}\text { A fixed-dose combination from Farmanguinhos } \\
\text { (Brazil)/DNDi was registered in Brazil in } 2008 \text {. } \\
\text { Given once per day over three days. Use outside } \\
\text { Brazil should be accelerated by production by } \\
\text { Cipla (India), and Indian registration in } 2012 \text {. } \\
\text { Prequalified by WHO in September } 2012 \text {. } \\
\text { Fixed-dose combination called artequin } \\
\text { granules ( } 50 \mathrm{mg} \text { artesunate/125 mg mefloquine), } \\
\text { originally registered in Portugal (2003) and now } \\
\text { sold in Africa in commercial markets. }\end{array}$ & e), b) & [34-38] \\
\hline $\begin{array}{l}\text { Artemisinin }(125 \mathrm{mg}) \\
\text { naphthoquine }(50 \mathrm{mg}) \times 8 \text { tablets }\end{array}$ & $\begin{array}{l}\text { Chinese Academy of Military } \\
\text { Medical Sciences, } \\
\text { Kunming Pharma Corp }\end{array}$ & Launched (China) & $\mathrm{ARCO}^{\circledR}$ & $\begin{array}{l}\text { Combination of poorly bio-available } \\
\text { artemisinin with naphthoquine. Given } \\
\text { either as a single dose or split twice } \\
\text { within the same day. Clinical studies } \\
\text { are not GCP compliant, and report on a } \\
\text { limited number of patients. Very little } \\
\text { preclinical data available for review. } \\
\text { Registered and promoted in more } \\
\text { than } 10 \text { countries. }\end{array}$ & a), h) & [39-41] \\
\hline
\end{tabular}




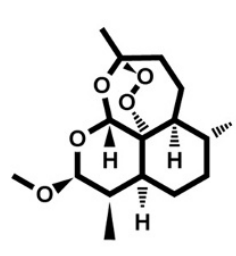

a) Artemether

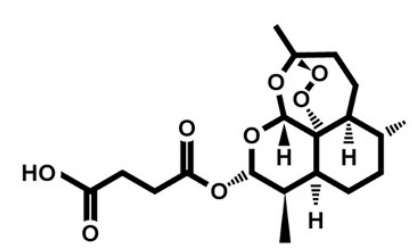

b) Artesunate

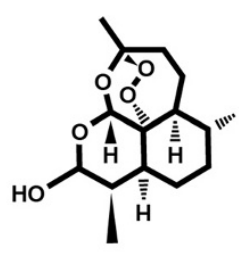

C) Dihydroartemisinin<smiles>Clc1ccc2c(N3CCN(CCCN4CCN(c5ccnc6cc(Cl)ccc56)CC4)CC3)ccnc2c1</smiles>

d) Piperaquine<smiles>CCCCN(CCCC)CC(O)c1cc(Cl)cc2c1-c1ccc(Cl)cc1/C2=C/c1ccc(Cl)cc1</smiles>

f) Lumefantrine

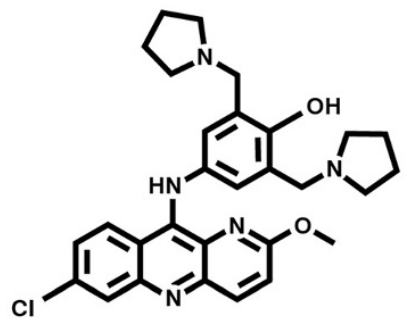

g) Pyronaridine
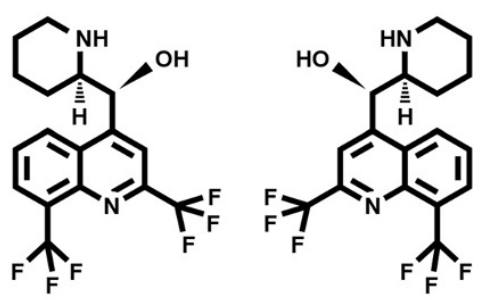

e) Mefloquine<smiles>CCN(CC)Cc1cc(Nc2ccnc3cc(Cl)ccc23)ccc1O</smiles>

g) Amodiaquine<smiles>CC(C)(C)NCc1cc(Nc2ccnc3cc(Cl)ccc23)c2c(c1O)CCCC2</smiles>

h) Naphthoquine

Figure 1 Chemical structures of anti-malarials described in Table 1.

efficacy and safety of naphthoquine [49], and the product has not yet been submitted for approval either to a Stringent Regulatory Authority or to WHO. The adult dose of artemisinin is high $(15-20 \mathrm{mg} / \mathrm{kg}$ ) [50], reflecting the poor bioavailability of the parent molecule.

Since over $85 \%$ of malaria patients are under five years old, development of child-friendly paediatric formulations remains the priority. Coartem ${ }^{\circledR}$ Dispersible (dispersible artemether-lumefantrine) is the first example of a taste-masked dispersible ACT, and was developed in a collaboration between MMV and Novartis [51]. Two other paediatric formulations are in development: a granule formulation of pyronaridineartesunate is to be submitted in early 2013 [52], and a dispersible formulation of DHA-piperaquine is planned for submission later in the same year. 


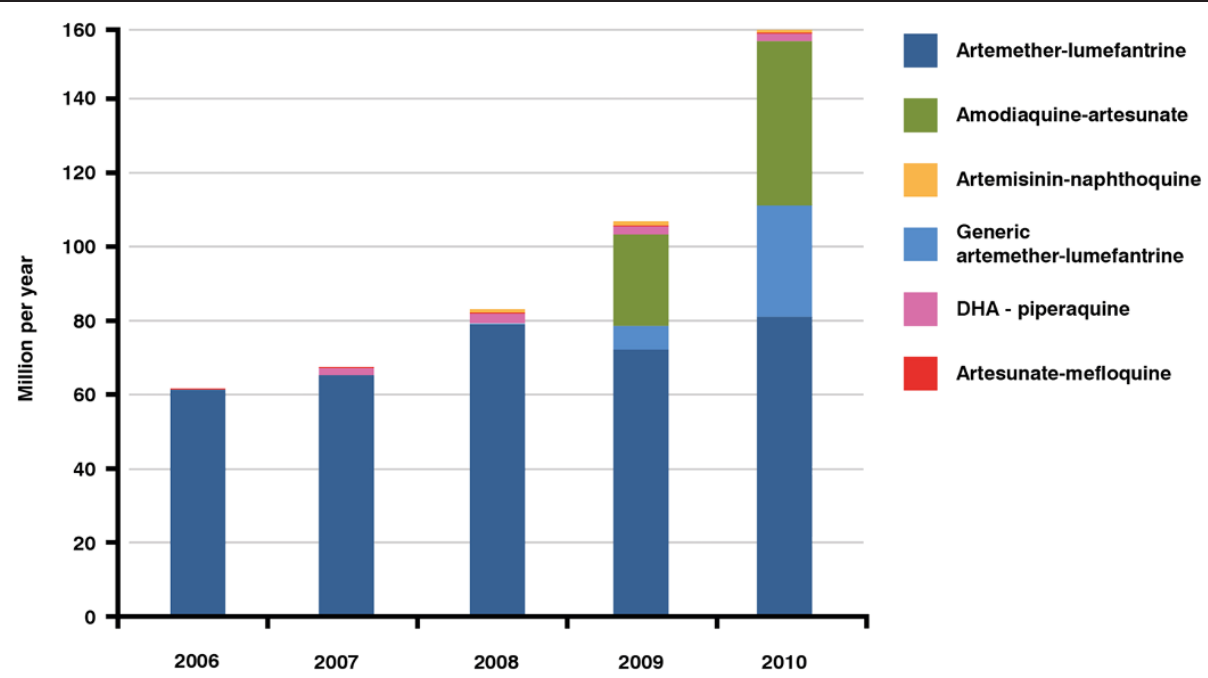

Figure 2 Sales (USD) of fixed-dose artemisinin combination therapy 2006-2010. These data are compiled from estimates supplied by the WHO-prequalified manufacturers and from data provided by AMFm and include only WHO-prequalified or Global Fund-approved generic versions of the medicines. Sales of DHA/piperaquine have been around two million per year, and naphthoquine artemisinin around one million per year. Mefloquine-artesunate numbers are significantly lower. These numbers compare well with the lower range of the estimates predicted by the Clinton Foundation [42]. The total number of malaria patients was estimated by WHO to have fallen to 225 million in 2009 [7].

Having more than one ACT available is an advantage. Each medicine will have a different impact, depending on the endemicity of the disease, the likelihood of re-infection, diet, co-medications, and the balance between the different forms of malaria: falciparum, vivax, malariae, ovale or knowlesi. These factors are summarized in Table 2. Resistance to partner drugs has already occurred in some countries, as has been demonstrated for amodiaquine [53], and this remains a threat for other therapy partners in many countries. Clinical signs of decreasing effectiveness of partners have been described, and loss of susceptibility to artemisinin has been reported in the Thai-Cambodia border regions $[54,55]$ as well as more recently in the Thai-Myanmar border region [56]. Having multiple first-line therapies in a country may help reduce the spread of resistance $[57,58]$.

Pyronaridine-artesunate is currently the only ACT with regulatory approval for activity against $P$. vivax, although it is widely assumed from field experience that other fixed-dose combinations will be equally active against $P$. malariae and the blood stages of $P$. vivax and P. ovale [31,32].

What challenges remain for the next generation of medicines? There is a continual threat of the emergence of resistance, both to artemisinin and the partner medicine. This will require new classes of medicines. In addition to this there are four areas of focus for drug discovery. Firstly, in the context of malaria eradication, there is a need for medicines that can be administered as a single dose, which will allow direct monitoring of administration and improve compliance. These should have activity against all existing resistant strains of parasite. Secondly, new medicines are needed that kill gametocytes, and thus prevent transmission. Thirdly, there is a need for medicines which prevent relapses of $P$. vivax. Finally there is a need for molecules with longer half-lives to give chemoprophylaxis or long-term protection against re-infection [58]. Figure 3 highlights the global portfolio of anti-malarial medicines in development organized by development stage (as of March 2012). Figure 4 shows the global portfolio of antimalarial medicines organized by therapeutic type, as discussed below.

\section{New treatments for severe malaria}

In 2010, a study in African children with severe malaria [61] showed a significant reduction of mortality using intravenous or intramuscular injections of artesunate in place of quinine, confirming earlier results in adult patients from Asia $[62,63]$. WHO now recommends artesunate as a firstline therapy in severe malaria [44]. $\operatorname{Artesun}^{\circledR}$ (a for injection), manufactured by Guilin Pharmaceuticals (see Table 3), was the first to be prequalified by WHO in 2010 [6]. The cost of approximately $\$ 1.00$ per treatment is justified by the better outcome compared with quinine [64]. As with ACT, it is important that there are multiple and reliable production sources, otherwise countries are reluctant to change treatments. IPCA manufactures artesunate for injection for India (see Table 4), and is planning to submit for prequalification.

Other therapies for severe malaria are in the pipeline. Most are adjunctive therapy, given on top of a schizonticide to reduce the sequelae of severe malaria, such as neurological damage. The track record of most potential 
Table 2 Relative product positioning for the fixed-dose artemisinin combination therapy, highlighting the differences between the medicines

\begin{tabular}{|c|c|c|c|c|c|c|}
\hline & $\begin{array}{l}\text { Artemether } \\
\text { lumefantrine }\end{array}$ & $\begin{array}{l}\text { Artesunate } \\
\text { amodiaquine }\end{array}$ & $\begin{array}{l}\text { Dihydroartemisinin } \\
\text { piperaquine }\end{array}$ & $\begin{array}{l}\text { Pyronaridine } \\
\text { artesunate }\end{array}$ & $\begin{array}{l}\text { Artesunate } \\
\text { mefloquine }\end{array}$ & $\begin{array}{l}\text { Artemisinin } \\
\text { naphthoquine }\end{array}$ \\
\hline Partner & Novartis, MMV & Sanofi, DNDi, (MMV) & sigma-tau, Pfizer, MMV & Shin Poong, MMV & $\begin{array}{l}\text { Farmanguinhos/DNDi, } \\
\text { Cipla; Mepha }\end{array}$ & $\begin{array}{l}\text { AMMS, Kunming } \\
\text { Pharma Corp }\end{array}$ \\
\hline Trade name & $\begin{array}{l}\text { Coartem }^{\circledR} ; \\
\text { Coartem- }^{\circledR} \text { Dispersible }\end{array}$ & $\begin{array}{l}\text { Coarsucam }^{\circledR} ; \\
\text { ASAQ-Winthrop }^{\circledR}\end{array}$ & Eurartesim ${ }^{\circledR}$ & Pyramax ${ }^{\circledR}$ & ASMQ & $\mathrm{ARCO}^{\circledR}$ \\
\hline Approval Date & $\begin{array}{l}\text { 1Q'01/1Q'09 } \\
\text { Swiss-Medic }\end{array}$ & $\begin{array}{l}\text { 2Q'07 Morrocco } \\
\text { Prequalified 4Q'08 }\end{array}$ & 4Q'11 EMA & $\begin{array}{l}\text { 1Q'12 EMA and } \\
\text { Prequalification }\end{array}$ & $\begin{array}{l}\text { 2Q'08 Brazil Prequalification } \\
\text { anticipated }\end{array}$ & 2005 China \\
\hline $\begin{array}{l}\text { Stringent } \\
\text { Approval }\end{array}$ & $\begin{array}{l}\text { Yes: CH, US-FDA, } \\
\text { WHO Prequalified }\end{array}$ & $\begin{array}{l}\text { No: Morocco, } \\
\text { WHO Prequalified }\end{array}$ & $\begin{array}{l}\text { EMA Submitted; approved } \\
\text { by the CHMP in Jun 2011, } \\
\text { and EU in Oct } 2011\end{array}$ & $\begin{array}{l}\text { EMA Submitted. Approved } \\
\text { by the Korean FDA } \\
\text { in Aug 2011; approved by } \\
\text { EMA in Feb } 2012\end{array}$ & $\begin{array}{l}\text { Farmanguinhos/DNDi } \\
\text { No: Brazil, WHO } \\
\text { Prequalification submitted; } \\
\text { Mepha product } \\
\text { approved in West Africa } \\
\text { and Portugal }\end{array}$ & $\begin{array}{l}\text { No: Sino-FDA for } \\
\text { the moment }\end{array}$ \\
\hline Formulation & $\begin{array}{l}\text { Tablet (adult), } \\
\text { dispersible flavoured } \\
\text { tablets (child) }\end{array}$ & $\begin{array}{l}\text { Dispersible tablets } \\
\text { for all ages }\end{array}$ & $\begin{array}{l}\text { Tablet (adult, child), dispersible } \\
\text { formulation for children } \\
\text { (submission in 2014) }\end{array}$ & $\begin{array}{l}\text { Tablet (adult), sachet with } \\
\text { granules (child), } \\
\text { (submission in 2014) }\end{array}$ & Tablet (adult, child) & Tablet (adult, child) \\
\hline Key Strengths & $\begin{array}{l}350 \text { million } \\
\text { treatments to date. } \\
\text { Paediatric formulation } \\
\text { is dispersible } \\
\text { and flavoured }\end{array}$ & $\begin{array}{l}\text { First line therapy in } \\
\text { francophone Africa. } \\
\text { Three-year shelf life. } \\
\text { Once per day, three } \\
\text { days. Paediatric dose. }\end{array}$ & $\begin{array}{l}\text { Once per day, three-day } \\
\text { treatment course. } \\
\text { Long terminal half-life of } \\
\text { piperaquine. Strong } \\
\text { post-treatment protection } \\
\text { of } 42 \text { days }\end{array}$ & $\begin{array}{l}\text { Once per day, three-day } \\
\text { treatment. Granulated } \\
\text { paediatric formulation } \\
\text { with taste-masking. } \\
\text { Best preclinical and } \\
\text { clinical data against } \\
\text { Plasmodium vivax. }\end{array}$ & $\begin{array}{l}\text { Once a day, three-day } \\
\text { treatment. Strong } \\
\text { post-treatment prophylaxis. } \\
\text { Active against } \\
\text { chloroquine resistant } P \text {. vivax. }\end{array}$ & $\begin{array}{l}\text { Single dose } \\
\text { treatment, } \\
\text { may be split } \\
\text { over two days. }\end{array}$ \\
\hline Key Weakness & Twice per day & $\begin{array}{l}\text { Amodiaquine } \\
\text { resistance } \\
\text { in some countries. } \\
\text { Gl adverse events }\end{array}$ & $\begin{array}{l}\text { Previous concerns on stability, } \\
\text { but data now support } \\
\text { two years under Zone } \\
\text { IVb conditions }\end{array}$ & $\begin{array}{l}\text { Tablets can only be given } \\
\text { to patients }>20 \mathrm{~kg} \text {. } \\
\text { Limited repeat dose data. } \\
\text { Currently only } \\
\text { recommended for a } \\
\text { single treatment }\end{array}$ & $\begin{array}{l}\text { Psychiatric and Gl adverse } \\
\text { events. Mefloquine-resistant } \\
\text { strains exist. Concern } \\
\text { over use where mefloquine } \\
\text { prophylaxis is recommended. } \\
\text { Currently relatively } \\
\text { expensive }(\$ 2.50)\end{array}$ & $\begin{array}{l}\text { No GCP clinical } \\
\text { studies or safety } \\
\text { data. Insufficient } \\
\text { information on } \\
\text { ARCO for children. } \\
\text { No stringent } \\
\text { regulatory approval }\end{array}$ \\
\hline $\begin{array}{l}\text { Market size \& } \\
\text { strength } 2010\end{array}$ & $\begin{array}{l}\text { First line treatment in } \\
35 \text { countries. } 82 \text { million } \\
\text { treatments ( } 37 \text { million } \\
\text { Coartem- }{ }^{\circledR} \text { Dispersible) } \\
\text { per year. Estimated } \\
21 \text { million are generic } \\
\text { artemether/lumefantrine. }\end{array}$ & $\begin{array}{l}45 \text { million (fixed-dose } \\
\text { combinations). } \\
\text { First line treatment } \\
\text { in } 17 \text { countries } \\
\text { (West Africa) }\end{array}$ & $\begin{array}{l}\text { Two million treatments } \\
\text { per year. Registered in } 30 \% \\
\text { of African countries. First } \\
\text { line therapy in Cambodia, on } \\
\text { treatment guidelines } \\
\text { in six countries }\end{array}$ & $\begin{array}{l}\text { Not launched yet. } \\
\text { Should be medicine of } \\
\text { choice in Asia/Pacific } \\
\text { dual-infection areas. }\end{array}$ & $\begin{array}{l}\text { Still relatively small } \\
\text { (200,000 treatments). } \\
\text { An Indian approval } \\
\text { would significantly } \\
\text { change this. }\end{array}$ & $\begin{array}{l}\text { Registered in more } \\
\text { than } 10 \text { countries. } \\
\text { Treats one million } \\
\text { patients per year. }\end{array}$ \\
\hline Stability & 24 months & 36 months & 24 months & $24+$ months & 36 months (Brazil) & Unknown \\
\hline $\begin{array}{l}\text { Public sector } \\
\text { pricing (USD) }\end{array}$ & $\begin{array}{l}\$ 0.74 \text { weighted average } \\
\text { (from } \$ 0.37-\$ 1.41 \\
\text { depending on weight) }\end{array}$ & $\begin{array}{l}\$ 0.60 \text { weighted average } \\
\text { (from } \$ 0.30-\$ 1.50 \\
\text { depending on weight) }\end{array}$ & $\begin{array}{l}\text { Estimated } \$ 0.90-\$ 1.10 \text { weighted } \\
\text { average (from } \$ 0.50-\$ 1.50 \\
\text { depending on weight). Final } \\
\text { price may be higher due } \\
\text { to DHA prices }\end{array}$ & $\begin{array}{l}\$ 1.10 \text { weighted average } \\
\text { (from } \$ 0.34-\$ 2.12, \text { lowest } \\
\text { to highest weight band). } \\
\text { Final price may be higher } \\
\text { due to artesunate prices }\end{array}$ & $\begin{array}{l}\text { Currently at } \$ 2.50 \text { per adult. } \\
\text { New mefloquine synthesis } \\
\text { should make the price similar } \\
\text { to other ACT }\end{array}$ & $\begin{array}{l}\text { Not sold in the } \\
\text { public sector. }\end{array}$ \\
\hline
\end{tabular}

\section{Tablet (adult) dispersible flavoured} Paediatric formulatio is dispersible 11 million are generic 24 months (from \$0.37-\$1.41
$\$ 0.60$ weighted average from \$0.30-\$1.50 depending on weight) 


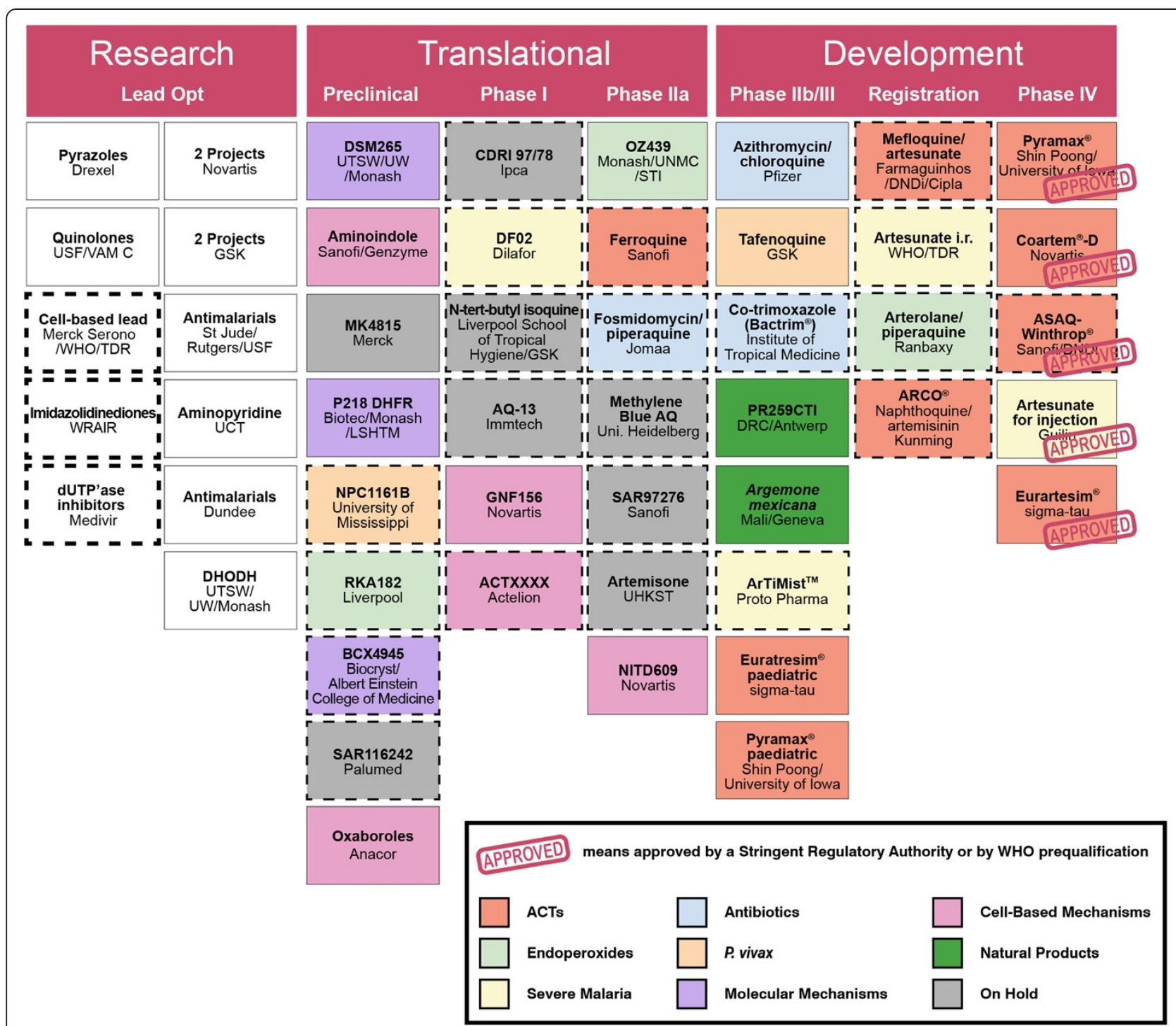

Figure 3 The global portfolio of anti-malarial medicines under development organized by development stage (as of March 2012). This includes all projects in formal regulatory preclinical safety and pharmacokinetic studies. Projects carried out in collaboration with MMV are shown in open boxes, whereas those with no active MMV involvement are shown with a dashed border. Data are from MMV internal reports [59], and Thomson Pharma. Compounds have been defined as 'on hold' when no significant progress along the development process has been made publicly available in the last 12 months. Natural products are defined as Herbal Medicinal Products undergoing testing in malaria patients in GCP quality studies, using standardized extracts. Updates of this figure are available on a quarterly basis [60]).

adjunct therapy has not been compelling, despite promising results in rodent studies. Adjunct approaches have generally shown little benefit. Recent reports on molecules such as $\mathrm{N}$-acetyl cysteine [123] and pentoxifylline [124] failed to show any significant benefit. One interesting example of adjunct therapy is DF-02 (sevuparin sodium), a heparin derivative with no anti-coagulation activity that blocks rosetting (a key event in severe malaria [68]), which has just completed Phase I trials. The only other molecule specifically being developed for this indication is a TLR-9 antagonist (E6446) from Eisai $[125,126]$. One success has been sublingual sucrose, which overcomes hypoglycaemia and, in a pilot study, resulted in a significant reduction in mortality [79].

The only new schizonticide specifically being proposed for severe malaria is SAR97276 (albitiazolium bromide), a choline antagonist [71,127]. It is being positioned in severe malaria because of its poor oral bioavailability. Phase II trials have shown higher doses are likely to be needed, at least for uncomplicated malaria [128]. However, given the size of the clinical trials required to show at least noninferiority regarding mortality compared to artesunate, no new product is likely to be developed for 


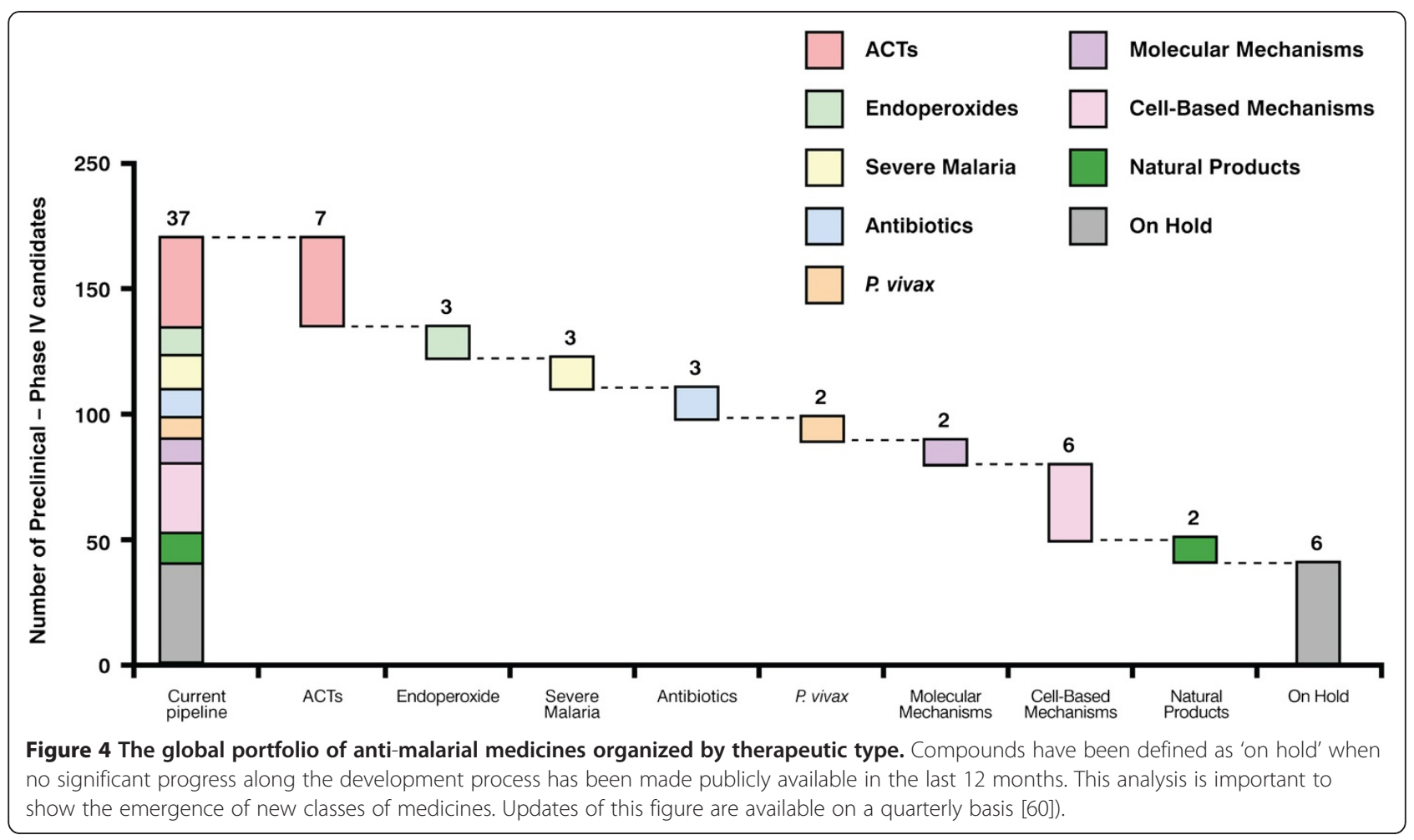

severe malaria unless artesunate becomes compromised by resistance in many countries.

The remaining medicines for severe malaria are all formulations of artemisinin derivatives. An intramuscular artemether is included in WHO's treatment guidelines and is produced by Kunming and Sanofi, amongst others (Table 3). No prequalified drug is available yet though, and there is a question mark over neurotoxicity as seen in preclinical trial animal species, but never confirmed in humans [129]. A sublingual spray of artemether from Eastland Medical Systems Ltd/Proto Pharma is being developed, but there is the risk that this product is most likely to be used as monotherapy treatment of uncomplicated malaria, in contradiction to WHO guidance. Finally, the UNICEFUNDP-World Bank-WHO Special Programme for research and training in Tropical Diseases (WHO-TDR) is developing artesunate suppositories as pre-referral treatment for patients with severe malaria, enabling them to receive at least some treatment prior to arrival at hospital. Clinical studies involving 12,068 patients showed that this increased the probability of survival of patients more than six hours away from hospital and for the youngest patients (100 mg dose) [66]. This product still needs to be approved by a Stringent Regulatory Authority and/or WHO prequalification, and will require a partner for manufacture and distribution. Adequate distribution of these suppositories to health centres more than six hours away from hospital will pose a significant challenge.

\section{New products in pregnancy}

In areas of high transmission, such as sub-Saharan Africa, malaria in pregnancy is a key cause of maternal, perinatal and neonatal morbidity. Case management of malaria seems possible with ACT in the second and third trimesters. Use of artesunate in the first trimester is contraindicated because of the side effects seen in preclinical safety models [130], although these effects have not yet been seen in the registries of patients who were accidentally treated with ACT during pregnancy [10]. The correct dosing of ACT in pregnancy needs to be better defined, as studies show that current doses may be inadequate [131-133]. As well as treatment, medicines may be used for intermittent preventive treatment in pregnancy (IPTp) to reduce infections and improve pregnancy outcomes. Options for therapy include azithromycin-chloroquine, mefloquine and also DHApiperaquine (Table 4). Azithromycin has poor activity against malaria, but synergizes with chloroquine, such that the combination kills even chloroquine-resistant strains [75]. Similar clinical synergy has been seen between azithromycin and quinine [74]. This combination is antibacterial, potentially reducing the risk for newborns and mothers from sexually transmitted bacterial infections [134]. Studies are on-going with another 
Table 3 Products under development for severe malaria, or as artemisinin monotherapy

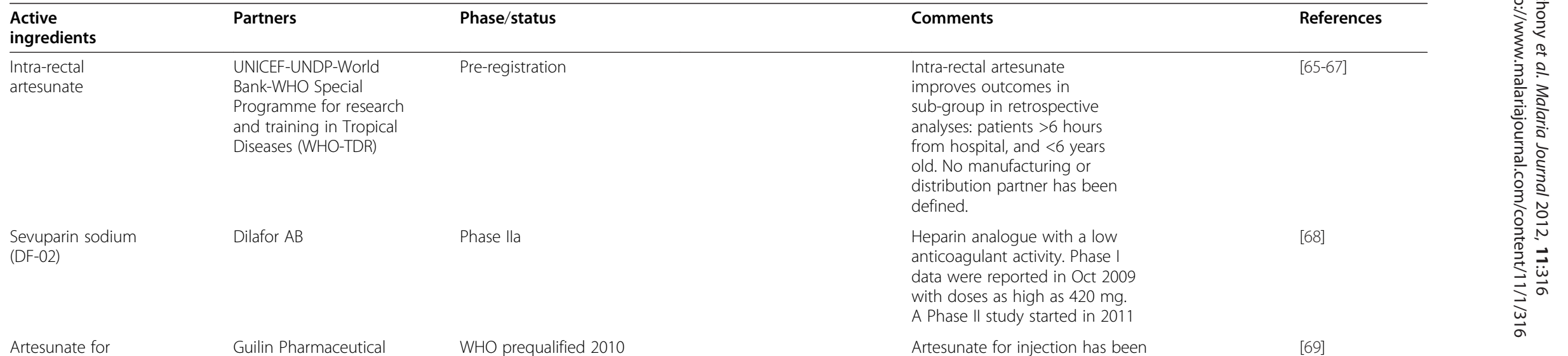

injection

Guilin Pharmaceutical

WHO prequalified 2010

ARH1 $(150 \mathrm{mg} / \mathrm{ml}$

artemether)

Lincoln

Pharmaceuticals

Launched (India) 2011

SAR97276 (albitiazolium bromide)

Sanofi/CNRS

Phase II

Star Medical

Protopharma Ltd
Phase III

ArTiMist $^{\text {TM }}$

(sublingual mouth spray)

Artesunate for injection has been

produced since 1987. In 2010,

Guilin gained WHO prequalification

(with support from MMV). The

clinical data in both the Aquamat

and Seaquamat studies used Guilin

material. Current price is $\$ 1.40$ per

$60 \mathrm{mg}$ vial, over 2500000 v

$60 \mathrm{mg}$ viat, over 2500000 vials sold

$\mathrm{ARH} 1$, an injectable formulation of

arteether (ethyl ether derivative of

artemisinin). It is oil soluble, has a

long elimination half-life (greater

than 20 hours), and is more stable

than other artemisinin compounds:

launched in India in Jun 2011.

Bisthiazolium choline uptake inhibitor,

not orally bio-available. Being developed

as an intramuscular injection for severe

malaria. Initial Phase II data showed

relatively poor efficacy in uncomplicated

malaria, and may require a higher dose.

Medicine could have the advantage of

being shipped in pre-filled syringes,

making delivery simpler.

An artemether sublingual mouth spray.

A Phase II study was conducted to

compare the efficacy of ArTiMist TM

and intravenous quinine in children

infected with severe malaria, or uncomplicated

malaria and gastro-intestinal complications

(NCT01047436). The difficulty is to make sure

this product does not break WHO's call for the 
Table 3 Products under development for severe malaria, or as artemisinin monotherapy (Continued)

\begin{tabular}{|c|c|c|c|c|}
\hline & & & $\begin{array}{l}\text { withdrawal of artemisinin monotherapy in } \\
\text { uncomplicated malaria. }\end{array}$ & \\
\hline $\begin{array}{l}\text { E6446 (TLR9 } \\
\text { antagonist) }\end{array}$ & Eisai Co Ltd & Preclinical & $\begin{array}{l}\text { Toll-like receptor antagonists. } \\
\text { TLR } 9 \text { antagonism has been } \\
\text { suggested to suppress } \\
\text { cerebral vascular lesions and } \\
\text { leakage of vascular contents. } \\
\text { The difficulties in interpreting } \\
\text { the murine data mean } \\
\text { additional proof of mechanism } \\
\text { in humans will be needed } \\
\text { before starting a severe malaria trial. }\end{array}$ & www.eisai.com \\
\hline
\end{tabular}


Table 4 New products under development

\begin{tabular}{|c|c|c|c|c|c|}
\hline $\begin{array}{l}\text { Active } \\
\text { ingredients }\end{array}$ & Partnership & Product name(s) & Phase & Comments & References \\
\hline $\begin{array}{l}\text { Azithromycin } 250 \mathrm{mg} \text {, } \\
\text { chloroquine } 155 \mathrm{mg}\end{array}$ & $\begin{array}{l}\text { Pfizer, MMV, } \\
\text { London School of } \\
\text { Hygiene and Tropical } \\
\text { Medicine }\end{array}$ & AZCQ & Phase III & $\begin{array}{l}\text { Azithromycin is a } \\
\text { macrolide requiring } \\
2000 \text { mg/day to be } \\
\text { effective as monotherapy } \\
\text { but shows clinical synergy } \\
\text { with chloroquine even } \\
\text { where chloroquine } \\
\text { resistance is as high } \\
\text { as } 50 \% \text {. Entered Phase III } \\
\text { for intermittent preventive } \\
\text { treatment of Plasmodium } \\
\text { falciparum malaria in } \\
\text { pregnancy (IPTp) in Oct } \\
2010 \text {. The primary outcome } \\
\text { is a reduction in the number } \\
\text { of subjects with suboptimal } \\
\text { pregnancy outcome, and } \\
\text { results should be available } \\
\text { in } 2014 \text {. }\end{array}$ & [72-76] \\
\hline $\begin{array}{l}\text { Trimethoprim/ } \\
\text { sulphamethoxazole }\end{array}$ & $\begin{array}{l}\text { Studies by Institute of } \\
\text { Tropical Medicine, } \\
\text { Antwerp in Zambia and } \\
\text { UCSF in Uganda }\end{array}$ & Co-trimoxazole & $\begin{array}{l}\text { Phase III } \\
\text { for malaria }\end{array}$ & $\begin{array}{l}\text { An antibacterial with activity } \\
\text { against malaria. Early data } \\
\text { in children showed similar } \\
\text { efficacy to amodiaquine } \\
\text { artesunate. A Phase III study } \\
\text { comparing against SP and } \\
\text { DHA-piperaquine is expected } \\
\text { to be completed in Jul } 2014 \text {. } \\
\text { A Phase III study with } 1,714 \\
\text { subjects in Zambia is testing } \\
\text { its effectiveness as prophylaxis } \\
\text { to prevent malaria in pregnancy, } \\
\text { expected to be completed in } \\
\text { Nov } 2011\end{array}$ & $\begin{array}{l}{[77-80]} \\
\text { NCT01053325 } \\
\text { NCT00948896 }\end{array}$ \\
\hline $\begin{array}{l}\text { Rbx11160/OZ277 } \\
150 \text { mg, } \\
\text { piperaquine } \\
\text { phosphate } 750 \text { mg }\end{array}$ & MMV, Ranbaxy & $\begin{array}{l}\text { Arterolane maleate }+ \\
\text { piperaquine } \\
\text { phosphate }\end{array}$ & Phase III & $\begin{array}{l}\text { First generation synthetic } \\
\text { peroxide (trioxalane), given } \\
\text { as one tablet per day for } \\
\text { three days. Arterolane as a } \\
\text { monotheraphy drug showed } \\
\text { lower efficacy than artesunate } \\
\text { with seven days of dosing. } \\
\text { A Phase III trial in India, } \\
\text { Bangladesh and Thailand } \\
\text { is now underway. } \\
\text { The medicine was approved } \\
\text { in India in early 2012. }\end{array}$ & $\begin{array}{l}{[81-86]} \\
\text { NCT00362050 }\end{array}$ \\
\hline OZ439 & $\begin{array}{l}\text { MMV, (University of Nebraska, } \\
\text { Monash University and } \\
\text { Swiss TPHI) }\end{array}$ & & $\begin{array}{l}\text { Phase lla } \\
\text { (monotherapy) }\end{array}$ & $\begin{array}{l}\text { Next-generation synthetic } \\
\text { peroxide. Phase I showed } \\
\text { OZ439 was safe at doses up }\end{array}$ & $\begin{array}{l}\text { [84] NCT01383096 } \\
\text { NCT00928083 }\end{array}$ \\
\hline
\end{tabular}


to $1,600 \mathrm{mg}$ as a single dose

and gives plasma concentrations

with anti-parasite activity up to

72 hours. A Phase lla study in

$P$. falciparum and $P$. vivax patients

was completed in mid-2012.

SSR97193, artesunate

Sanofi

Ferroquine

-aminoquinoline active in vitro

against multidrug resistant

P. falciparum. Phase II studies

showed that it is active in

combination with artesunate in

African adults and children. Project

was put on hold, presumably

wecause of insufficient product

differentiation.

Fosmidomycin is a DOXP inhibitor,

used in combination with the

antibiotic clindamycin. A study

in children showed good tolerability

and $94 \%$ efficacy. A further Phase $\|$

was completed in Sept 2011.

Methylene blue, Ruprecht-Karls-Universität

chloroquine

Heidelberg, DSM

Phase II

Methylene blue was originally

suggested by Paul Ehrlich.

The combination MB-CQ is

safe in adults and children

with or without G6PD deficiency.

Local acceptability studies imply

discolouration of urine is not

seen as a major issue.

Phase lla

(monotherapy)

Spiroindolone suppresses protein

synthesis in the parasite, working

through PfATP4. NITD609 has the

pharmacokinetic properties

compatible with once-daily oral

dosing for the potential treatment

of falciparum and vivax malaria.

A Phase lla trial started in

December 2011

Phase

compound of undisclosed

structure with similar parasite

reduction rates as chloroquine

Completed Phase

in summer 2012

An imidazolopiperazine active

against blood, liver and

gametocytes, with stages of

Plasmodium, and active in murine

models. Preclinical safety studies
87-91]

$[100,101]$ 
Table 4 New products under development (Continued)

started in the first quarter of 2011

and Phase I early in 2012

Oxaboroles

Anacor, MMV

DSM265

University of Texas

Southwestern, MMV

University of Washington

Monash University

Merck, MMV

MK4815

Preclinical

A new class of oxaboroles.

Highly potent against

P. falciparum parasites, and

curative in animal models.

Has a good safety profile and

excellent drug-like properties,

and low cost-of-goods.

Preclinical

A dihydroorotate dehydrogenase

(DHODH) inhibitor. In June 2010,

a compound was chosen from

the inhibitor series for full

preclinical development. First in

human studies are planned for

early 2013.

Preclinica

A cell-based inhibitor that has demonstrated potency against P. falciparum malaria when tested in vivo. Its mechanism

of action appears to involve the mitochondrial involve the mitoch ondrial electron transport chain of the parasite and when administered concentrates in infected erythrocytes. Due to safety issues, the molecule is stil in preclinical evaluation.

A dihydrofolate reductase inhibitor binds with high affinity to the wild-type and resistant DHFR enzymes and has an excellent ADME-PK profile. Currently in preclinica provelopment, although there development, although there are concerns about the impact of pre-existing DHFR mutant stains of parasite.

Preclinical

An aminoindole, with activity against both $P$. falciparum and P. knowlesi. This family has the advantage that it has been impossible so far to produce resistant mutant strains of parasite. Preclinical evaluation started in early 2011.

Lead compound from a series of tetraoxanes with rapid 
intermediate between 02277

and OZ439. Next-generation

compounds are currently being

tested.

BCX4945

Albert Einstein College of

Medicine, Biocryst

Pharmaceuticals,
On Hold

Parasites cultured in human

erythrocytes can be

$[109,110]$

killed rapidly by this purine

nucleoside phosphorylase (PNP)

(immucillin-H).

Purine salvage pathways

in the mouse suggest a

mechanism for lack of

in vivo activity, and that

these compounds

will have to be tested

directly in human

challenge models.

A trioxane anti-malarial

candidate, shown

initially to be safe in

pre-clinical studies.

An IND was approved in

March 2010 in India, but no

further progress has been reported.

AQ-13 is another

4-aminoquinoline, active

against chloroquine-resistan

P. falciparum infection. A

Phase I study with 126 individuals

was successfully completed in 2005

but no further development was

reported. The compound has

no significant advantages

over other 4-aminoquinolines.

On hold

\section{$\mathrm{N}$-tert-butyl isoquine was}

developed as a safer

alternative to amodiaquine.

In May 2008, a single-blinded,

placebo-controlled, randomized

Phase I trial was initiated in

Phase I trial was intiated in

healthy volunteers. The trial was stopped

later in 2008 as a result of adverse events,

at the highest dose. Experiments are

ongoing to recalculate the estimated

human effective dose. 
Table 4 New products under development (Continued)

SAR116242/PA1103

Palumed, MMV

Artemisone

Hong Kong University of

Science and Technology,

(MMV, Bayer)

Artemefone

(semisynthetic

artemisinin

derivative)
On hold

On hold
A fusion compound containing a

trioxane ring and a 4-aminoquinoline

group. It entered preclinical development

in 2007, but has not progressed into

human studies.

In preclinical studies, artemisone,

a new artemisinin derivative

proposed to have enhanced safety

over artesunate. Currently being

discussed as an option for treating

artemisinin-resistant malaria,

although clinical trials have not

started, and a commercial partner is still

being sought. 
antibiotic combination, co-trimoxazole (sulphamethoxazole-trimethoprim), in HIV co-infected women, by the Institute of Tropical Medicine, Antwerp and University of California, San Francisco, USA (NCT00948896).

The other medicine commonly discussed for IPTp is mefloquine, which shows significant clinical benefit [135]. Two complications are side effects and cost. Mefloquine causes nausea and neuropsychiatric disorders amongst Caucasian volunteer cohorts [136], but studies show that side effects are balanced by the positive influence of the drug [37]. On-going efforts sponsored by MMV have optimized mefloquine synthesis, with the potential to lower the cost-per-treatment more than twofold to less than $\$ 400 / \mathrm{kg}$. The use of ACT in IPTp is complicated by concerns over the use of artemisinin in pregnancy, and also the concern over using the same medicines for prophylaxis and treatment.

\section{Next generation endoperoxides}

The world demand for artemisinin products is large. Treating all malaria cases could require in excess of 200 tonnes of artemisinin per year. The price of artemisinin from plants has fluctuated widely (between $\$ 300 / \mathrm{kg}$ and $\$ 1,500 / \mathrm{kg}$ ), and material can take up to two years from order to delivery. This creates a problem for low-cost therapy. Three solutions have been proposed: first, the use of higher-yielding seeds [137]; second, using yeast for scalable production in bioreactors [138], where Sanofi plans first commercial tonne-scale production in 2012; and third, to make synthetic endoperoxides.

MMV established a project with the University of Nebraska, the Swiss Tropical and Public Health Institute, and Monash University to develop synthetic endoperoxides in 2000. The first clinical product was OZ277 (now called Rbx11160 or arterolane). This showed activity in Phase IIa trials [139] in uncomplicated falciparum malaria. However, the clinical activity was not as good as artemisinin, showing adequate clinical and parasitic response at day 28 (ACPR28) of 60-70\% after seven days' treatment, compared with a 95\% response with artesunate. The plasma exposure was non-linear above $100 \mathrm{mg}$, and OZ277/Rbx11160 was unstable in infected blood (presumably due to free ferrous iron) [84]. Despite this, Ranbaxy have completed a Phase III study of OZ277/Rbx11160 (150 $\mathrm{mg}$ ) and piperaquine $(750 \mathrm{mg})$, and the product has been approved in India. This is the first medicine to be developed in India. The lower efficacy of OZ277/ Rbx11160 compared to artesunate [84] may increase the pressure for resistance against piperaquine, which is already being reported in Cambodia [140]. MMV's nextgeneration clinical candidate, OZ439, has superior pharmacokinetics: exposure is dose-proportional, similar in patients and volunteers, and plasma concentrations remain above the mean parasiticidal concentration for more than 72 hours after a single dose, suggesting it could be part of a single-dose cure [84]. Phase IIa studies in uncomplicated P. vivax and $P$. falciparum malaria have now been completed. The next stage is to investigate drug interactions in volunteers with potential partner drugs.

Three other synthetic endoperoxides have been in preclinical development (Table 4). RKA 182 is a tetraoxane, from the Liverpool School of Tropical Medicine and the University of Liverpool, with a simpler, more symmetrical molecule that may have a lower cost-per-treatment. Preclinical testing showed it to be superior to OZ277 [107], and further work is ongoing to identify a molecule with pharmacokinetics similar to OZ349. CDRI 99/411[141] from the Central Drug Research Institute in India was taken into Phase I by IPCA but the project is currently on hold. A trioxalane (a six-membered endoperoxide ring), fused with a 4-aminoquinoline, was produced by Palumed (PA1103/SAR116242) [118], but was abandoned in preclinical development. Finally, the semisynthetic endoperoxide, artemisone, showed good activity in Phase II studies in 2009 [121]. Potential advantages of artemisone include lower dose and potential activity in artemisinin-resistant malaria (given the additional thiomorpholino ring). Initially the compound was developed by Bayer, however the company is no longer involved with this molecule and a new partner is needed before clinical studies can recommence.

\section{Preventing the relapse of Plasmodium vivax malaria}

The current gold standard for preventing relapse in $P$. vivax or $P$. ovale is primaquine, an 8 -aminoquinoline [142]. There are two major issues with its use: 14 days' treatment is required, reducing compliance to close to zero [143], and there is an elevated risk of haemolysis in patients with glucose-6-phosphate dehydrogenase (G6PD) deficiency [142], present in 10-20\% of the population in malaria-endemic areas [144].

The only molecule currently in clinical development for preventing relapses is tafenoquine (WR 238605), another 8-aminoquinoline originally developed by the Walter Reed Army Institute of Research. Tafenoquine has a longer half-life in man, with potential as a singledose treatment [144-146]. The clinical programme is being partnered by GSK and MMV and has now started recruiting patients for a Phase II dose-finding study. Initial results on both the relative efficacy and safety in G6PDdeficient subjects, compared with chloroquine alone or compared to primaquine, are expected towards the middle of 2013. NPC1161B is a related 8-aminoquinoline from the University of Mississippi [147], active against relapses in primate models. At this stage, it is difficult to find any superiority of NPC1161B over tafenoquine, apart from its 
effect on insect stages [148], highlighting the need for a preclinical model for G6PD-dependent erythrocyte deformation and haemolysis.

\section{Other products in clinical development}

The remaining projects in development fall into several distinct groups:

(a) Next-generation aminoquinolines. There are a number of 4-aminoquinolines or amino-alcohols in development. These are positioned as the nextgeneration molecules after the current ACTs. As there are already six artemisinin combination products with some form of regulatory dossier, and all have ACPR28 >95\%, this makes the hurdles extremely high for such new molecules. A prime advantage would be to have molecules with better safety profiles, but it is almost impossible to predict this pre-clinically. A lower clinical dose could be an advantage (total doses of $1,920 \mathrm{mg}$ lumefantrine, 1,620 mg amodiaquine or 2,880 mg piperaquine are required over three days for adults [44]), especially if this could be given as a single dose. Phase II studies have been completed on ferroquine (from Sanofi) in combination with artesunate, where total doses as low as $300 \mathrm{mg}$ have shown clinical activity (see Table 4). Naphthoquine (from Kunming) is used in a dose of only $400 \mathrm{mg}$ in the combination with artemisinin, and both of these compounds show some promise. Two other aminoquinolines are on hold: AQ-13 is a modified chloroquine, showing similar exposure in Phase I [147], but which is not sufficiently differentiated. N-tertiary-butyl isoquine is a modified amodiaquine from the University of Liverpool and the Liverpool School of Tropical Medicine $[115,116]$, which has not been progressed since the end of Phase I studies.

(b) Antibiotic combinations. In addition to the azithromycin-chloroquine and sulphamethoxazoletrimethoprim combination discussed above in the pregnancy section, two other antibiotic-containing combinations are being explored (see Table 4). The 1-deoxy-D-xylulose 5-phosphate (DOXP) inhibitor, fosmidomycin, has been developed with the lincosamide antibiotic, clindamycin, by Jomaa Pharma GmbH (NCT00217451). Fosmidomycin appears to have a rapid parasite-killing activity in adult patients, but not in children, although a full time-course has not been published, and the dose of $3,600 \mathrm{mg} /$ day may ultimately be problematic [149]. Antibiotic combinations could be considered as fallback therapy in the event that artemisinin resistance becomes a significant clinical issue. Under these circumstances, the standard of care could become seven days quinine plus antibiotic, and therefore the barrier to success would be lower. However, as new classes of molecules enter clinical development from discovery, the relative importance of these antibiotics decreases. The major challenge of effectively managing a portfolio of anti-malarial medicines is to balance the investment in old classes of molecules with that in new molecules with unknown risks and opportunities.

(c) New compounds against molecular targets. Two compounds against molecular targets have also moved into development. The enzyme dihydroorotate dehydrogenase (DHODH) is known to be essential for the survival of the parasite. A new inhibitor, DSM1, was identified from highthroughput screening at the University of Texas, and the three-dimensional structure of the enzymeinhibitor complex has been resolved [103]. An improved version, DSM265 has recently entered preclinical development. A next-generation inhibitor of dihydrofolate reductase, P218, entered preclinical development, and work has been focused on allaying fears about the propensity to select for pre-existing mutations in dihydrofolate reductase (DHFR) from the widespread use of pyrimethamine [150]. BCX4945, an inhibitor of purine nucleoside phosphorylase developed for other indications, has been suggested for use in malaria [110]. However, the compound showed no activity in mouse models.

(d) New compounds from cellular screens. Despite these success stories, screening 'validated' molecular targets has not been particularly fruitful over the past few years, an experience shared with antibacterial drug discovery [151]. Screening directly against the whole parasite has, therefore, been prioritized. Over the past few years, six million compounds (from over 20 companies and university groups) have been screened against the parasite in the intra-erythrocytic stages. This has resulted in almost 30,000 (0.5\%) compounds identified with activity at micromolar levels [152-154]. This rate is higher than predicted, and also is higher than that seen when screening molecular targets. The first compound to be developed from the parasitefocused screening is NITD609, a spiroindolone developed by the Novartis Institute for Tropical Diseases in Singapore as part of a collaboration with the Swiss Tropical and Public Health Institute and the Dutch Biomedical Primate Research Center [101]. This is now in Phase IIa clinical studies. The move from screen to Phase IIa within five years is a tremendous achievement for a new class of molecules. Target identification in parallel to lead optimization suggested the P-type cation- 
transporter ATPase 4 (PfATP4), which interestingly had been characterized, but not prioritized as a target [155]. The second compound from this collaboration is GNF156, an imidazolopiperazine identified by the Genome Foundation of Novartis in San Diego as part of the same collaborative network. It exhibits in vitro potency against blood, liver schizont and gametocyte stages of Plasmodium, (but not the hypnozoites), is orally efficacious in mouse malaria models [156], and has recently entered human volunteer studies.

Several other molecules coming from similar screens are entering development. Novel oxaborolecontaining compounds synthesized by Anacor have been identified by screening their library against Plasmodium. Genzyme identified an aminoindole in a project with the Broad Institute in Boston [106], which is particularly interesting since no resistant parasite strains have yet been identified. Merck identified MK4815, also based on cellular assays, which underwent preclinical evaluation with MMV and has not progressed further due to a narrow safety window. Finally, the Swiss biotechnology company Actelion identified an anti-malarial from a parasite screen of a highly focused set of molecules, and this compound is also in Phase I clinical trials.

(e) Other compounds. Methylene blue has long been known to have an activity against malaria [99], presumably by changing the redox potential of the infected cell. Phase IIa studies have been carried out with other compounds in combination with chloroquine. The results are interesting, but the combination therapy is less active than ACT [98]. Recent suggestions of activity against the gametocytes may require a re-evaluation of its clinical utility.

\section{Natural products}

There is a substantial interest in natural products and the possibility for their role as new anti-malarials. This is not a new departure: three of the mainstays of malaria treatment come from natural products: quinine, lapachol (which led to atovaquone) and artemisinin. The Chinese method dao-xing-ni-shi - 'acting in the reversed order' - was used by Chen Guofu [157] to investigate herbal extracts used by a population as their anti-malarial treatment. However, many of the extracts known to 'cure' malaria have never been observed in situations where (i) it is clear that the patients had malaria (defined by WHO as fever and parasites); (ii) how much of the extract they consumed; and (iii) whether they had malaria seven or 14 days later. In addition, given that most African adults have some sort of immune protection against the malaria parasite, a placebo rate of around $70 \%$ is possible, confounding the studies.

The identification of new active natural products in malaria has been disappointing [157]. There have been relatively few new compounds identified by purifying individual natural product molecules from extracts and screening them individually against the parasite. This has led to a call for using molecules in combination [159], or for a return to more observational clinical studies [160].

To date, analysis of the literature has found few natural product extracts in development where the human data are clear. One is an extract of Nauclea pobeguinii, a plant from the Democratic Republic of Congo, which showed a parasite and clinical response of $90.3 \%$ at day 14 in 65 patients in Phase II [161]. Although this is below the WHO threshold, it is a much better result than would be seen with either a quinine or artemisinin extract. The second natural product is an extract of Argemone mexicana (Mexican poppy) from Mali, which shows a cure rate of $89 \%$ at day 28 in Phase II studies [162]. In both cases, the challenge is to produce standardized extracts for clinical studies. Eventually standardized extracts could become treatments by themselves, similar to the Indian Ayush-64, the Ghanian Phyto-laria, and the standard treatment (Argemone mexicana) in Mali [158]. Moreover, if the active ingredient was identified, this could be developed into a standardized form. There is a strong likelihood that the active ingredient will be a metabolite of the original extract, as these extracts are relatively weak in in vitro assays. Therefore, one priority is to analyse the human metabolism of these interesting extracts.

\section{Significant challenges ahead: changing priorities for the eradication agenda}

The announcement of a malaria eradication agenda and its subsequent elaboration by various working groups has helped identify priorities for the future [1]. Beyond that, new medicines would ideally fit several TPPs (for more details please see [3]).

(a) Single-dose cure. Not only would changing from a three-day course of therapy to a single dose decrease the cost of treatment but also it would enable directly observed administration, making it far less easy for patients to take an incomplete course of treatment. Medicines that are safe enough to be given as a single dose are needed, that stay at the site of action for at least two parasite life cycles. These medicines need to be active against all species of malaria, especially drug-resistant strains. In addition, it must be clear that the compounds do not easily select for resistant phenotypes in strains 
that have not yet emerged. The difficulty of studying artemisinin resistance is the current lack of stable cell assays and molecular markers, which make it almost impossible to characterize drug action.

(b) Transmission-blocking. Preventing the parasite from being transmitted back to the mosquito in a blood meal would break the cycle of transmission. Compounds are being sought that are active against the gametocyte stage, particularly stage five. In the next few years, it is hoped that high-throughput screening will be available to screen larger collections of molecules specifically for this task. Understanding the activity of compounds against $P$. vivax gametocytes is further complicated by the lack of stable culture methods, and also because clinically they appear early in the infection transmission may have happened before a patient seeks medical attention.

(c) Hypnozoite treatment and relapse prevention. For $P$. vivax and $P$. ovale, an additional hurdle is to prevent relapse of the hypnozoite or dormant liver form. Attempts are underway to develop biological assays for efficacy, and first successes have been achieved [163]. The availability of an assay means that it is now possible to profile new chemical series to see whether they have activity against both the blood and the liver stages. This has led to some success in hits-to-leads chemistry, which shows activity against hypnozoites.

(d) Chemoprevention. The most advanced vaccine against malaria is the RTS,S vaccine (currently planned for launch in 2015 for children, which caused a $50 \%$ reduction in incidence of acute falciparum infections in young children in initial Phase III studies [164-166]). There remains a significant need for a molecule which can protect the adult population from infection. As malaria becomes less common in Africa, the natural immunity within the population will fall, and the continent's population would be as at risk of malaria infection as western travellers are today. New protective medicines will need long half-lives. Depot formulations are possible, but then the medicines must be potent with a human daily dose of less than $10 \mathrm{mg}$, and preferably less than $1 \mathrm{mg}$.

Not all molecules meet all criteria above, as new malaria medicines will be a combination of several active ingredients. Understanding the activity of the compounds against each stage in the Plasmodium life cycle (a Malaria Lifecycle Fingerprint) is important as early as possible in the development process to allow a focused development strategy and prioritization between molecules.
In addition, three factors are critical for the development of new medicines. First, safety and tolerability; since these medicines will be used in areas where pharmacovigilance systems are not always completely effective. Second, an appropriate speed of action; for blood stage medicines, the patients have become used to the speed of action of artemisinin. Third, medicines need to be potent; many of the current medicines are active at adult doses approaching $1 \mathrm{~g}$ per day. If the next-generation of medicines are more potent, this can greatly impact the cost of treatment. Cost reductions will be much more likely to come from doses that are lower than current therapy, rather than from simpler, cheaper molecules.

\section{Conclusions}

The pipeline of new molecules targeting malaria is much richer now than it was two years ago [167]. Two significant events have occurred: first, new medicines have moved down the pipeline, specifically the prequalification of artesunate for severe malaria and the stringent regulatory approval of DHA-piperaquine and pyronaridineartesunate as new fixed-dose anti-malarials. Second, and arguably more interesting, is the number of new molecules and new classes of molecules that are entering the pipeline. There are at least seven new compound families that have been discovered in the past five years. This is a rich portfolio and reflects the commitment of the field as a whole. Nonetheless, from a portfolio point of view there are still gaps. The chance that a new molecule entering Phase I studies will make it to registration is still around $20 \%$ for anti-infectives, and for a new combination two molecules would be needed. In addition, new TPPs have emerged from the malaria eradication agenda and compounds need to be measured against these, focusing on transmission-blocking and anti-relapse potential. With the sustained commitment of all of partners - donors, scientists, academics and the pharmaceutical industry - the next decade will be a very exciting time to be in clinical development of new therapeutics for malaria.

\section{Abbreviations}

ACPR28: Adequate clinical and parasitological response at day 28 post treatment; ACT: Artemisinin combination therapy; AMFm: Affordable medicines facility - malaria; Sino FDA: Chinese authorities; DHA: Dihydroartemisinin; DNDi: Drugs for Neglected Diseases initiative; EMA: European Medicines Agency; FDA: Food \& Drugs Administration; G6PD: Glucose-6-phosphate dehydrogenase; IPTp: Intermittent preventive treatment in pregnancy; MMV: Medicines for Malaria Venture; SLS: Sublingual sugar; TPPs: Target Product Profiles; TDR: UNICEF-UNDP-World Bank-WHO Special Programme for research and training in Tropical Diseases; WHO: World Health Organization.

\section{Competing interests}

The authors declare that they have no competing interests, beyond the fact that MMV is involved in supporting the development of some of these medicines. This paper was designed as an objective review of the entire worldwide portfolio of medicines in development, and the authors apologise in advance to all colleagues where space constraints prevented a fuller description of the molecules. 


\section{Authors' contributions}

MA and TW prepared the data tables; the commentary was written by TW, JB, JM and SD. All authors read and approved the final manuscript.

\section{Acknowledgements}

We thank all the team at MMV: the staff and the Expert Scientific Advisory Committee (ESAC), and its Chairs over the years: Drs Simon F Campbell, Win Gutteridge, Dennis Schmatz, David McGibney, and R Kip Guy. Thanks also to all of our collaborators for their commitment to making this portfolio a reality. Most of all the thanks go to our patients and their families for their contribution to changing the face of this devastating disease.

Received: 26 April 2012 Accepted: 21 July 2012

Published: 7 September 2012

\section{References}

1. Alonso PL, Brown G, Arevalo-Herrera M, Binka F, Chitnis C, Collins F, Doumbo OK, Greenwood B, Hall BF, Levine MM, Mendis K, Newman RD, Plowe CV, Rodriguez MH, Sinden R, Slutsker L, Tanner M: A research agenda to underpin malaria eradication. PLoS Med 2011, 8:e1000406.

2. Wells TN, Alonso PL, Gutteridge WE: New medicines to improve control and contribute to the eradication of malaria. Nat Rev Drug Discov 2010 8:879-891.

3. Target Product Profiles, MMV website 2012. http://www.mmv.org/researchdevelopment/essential-information-scientists/target-product-profiles.

4. Maude RJ, Woodrow $C J$, White $L$ : Artemisinin antimalarials: preserving the "magic bullet". Drug Dev Res 2010, 71:12-19.

5. White NJ: Antimalarial drug resistance. J Clin Invest 2004, 113:1084-1092.

6. WHO: WHO List of Prequalified Active Pharmaceutical Ingredients. Geneva: World Health Organization; 2012. http://apps.who.int/prequal/.

7. WHO: World Malaria Report. Geneva: World Health Organization; 2010 http://www.who.int/malaria/publications/atoz/9789241564106/en/index. html.

8. Teklehaimanot A, Singer B, Spielman A, Tozan Y, Schapira A: Coming to grips with malaria in the new millenium. London: Earthscan; 2005.

9. Access Campaign, Medecins sans Frontières: Ten stories that mattered in access to medicines in 2011 2012. http://www.msfaccess.org/our-work/ driving-medical-innovation/article/1715.

10. Kaye DK, Nshemerirwe R, Mutyaba TS, Ndeezi G: A randomized clinical trial comparing safety, clinical and parasitological response to artemetherlumefantrine and chlorproguanil-dapsone in treatment of uncomplicated malaria in pregnancy in Mulago hospital, Uganda. J Infect Dev Ctries 2008, 2:135-139.

11. Ngasala BE, Malmberg M, Carlsson AM, Ferreira PE, Petzold MG, Blessborn D, Bergqvist Y, Gil JP, Premji Z, Martensson A: Effectiveness of artemetherlumefantrine provided by community health workers in under-five children with uncomplicated malaria in rural Tanzania: an open label prospective study. Malar J 2011, 10:64.

12. Valecha N, Srivastava P, Mohanty SS, Mittra P, Sharma SK, Tyagi PK, Pradhan $K$, Dev $V$, Singh R, Dash AP, Sharma YD: Therapeutic efficacy of artemether-lumefantrine in uncomplicated falciparum malaria in India. Malar J 2009, 8:107.

13. Kabanywanyi AM, Lengeler C, Kasim P, King'eng'ena S, Schlienger R, Mulure N, Genton B: Adherence to and acceptability of artemether-lumefantrine as first-line anti-malarial treatment: evidence from a rural community in Tanzania. Malar J 2010, 9:48.

14. Falade CO, Ogunkunle OO, Dada-Adegbola HO, Falade AG, De Palacios PI, Hunt $P$, Virtanen M, Oduola AM, Salako LA: Evaluation of the efficacy and safety of artemether-lumefantrine in the treatment of acute uncomplicated Plasmodium falciparum malaria in Nigerian infants and children. Malar J 2008, 7:246.

15. Assefa A, Kassa M, Tadese G, Mohamed H, Animut A, Mengesha T: Therapeutic efficacy of Artemether/Lumefantrine (Coartem(R)) against Plasmodium falciparum in Kersa. South West Ethiopia. Parasit Vectors 2010, 3:1.

16. Abdulla S, Sagara I: Dispersible formulation of artemether/lumefantrine: specifically developed for infants and young children. Malar J 2009 8 Suppl 1:S7

17. Borrmann S, Sallas WM, Machevo S, Gonzalez R, Bjorkman A, Martensson A, Hamel M, Juma E, Peshu J, Ogutu B, Djimde A, D'Alessandro U, Marrast AC, Lefevre G, Kern SE: The effect of food consumption on lumefantrine bioavailability in African children receiving artemether-lumefantrine crushed or dispersible tablets (Coartem) for acute uncomplicated Plasmodium falciparum malaria. Trop Med Int Health 2010, 15:434-441.

18. Ndiaye JL, Faye B, Diouf AM, Kuete T, Cisse M, Seck PA, Brasseur P, Same Ekobo A, Lameyre V, Gaye O: Randomized, comparative study of the efficacy and safety of artesunate plus amodiaquine, administered as a single daily intake versus two daily intakes in the treatment of uncomplicated falciparum malaria. Malar J 2008, 7:16.

19. Sirima SB, Tiono AB, Gansane A, Diarra A, Ouedraogo A, Konate AT, Kiechel JR, Morgan CC, Olliaro PL, Taylor WR: The efficacy and safety of a new fixed-dose combination of amodiaquine and artesunate in young African children with acute uncomplicated Plasmodium falciparum. Malar J 2009, 8:48.

20. Asante KP, Abokyi L, Zandoh C, Owusu R, Awini E, Sulemana A, AmengaEtego S, Adda R, Boahen O, Segbaya S, Mahama E, Bart-Plange C, Chandramohan D, Owusu-Agyei S: Community perceptions of malaria and malaria treatment behaviour in a rural district of Ghana: implications for artemisinin combination therapy. BMC Public Health 2010, 10:409.

21. Adjei GO, Kurtzhals JA, Rodrigues OP, Alifrangis M, Hoegberg LC, Kitcher ED, Badoe EV, Lamptey R, Goka BQ: Amodiaquine-artesunate vs artemetherlumefantrine for uncomplicated malaria in Ghanaian children: a randomized efficacy and safety trial with one year follow-up. Malar J 2008, 7:127.

22. Zwang J, Olliaro P, Barennes H, Bonnet M, Brasseur P, Bukirwa H, Cohuet S, D'Alessandro U, Djimde A, Karema C, Guthmann JP, Hamour S, Ndiaye JL, Martensson A, Rwagacondo C, Sagara I, Same-Ekobo A, Sirima SB, van dB I, Yeka A, Taylor WR, Dorsey G: Randrianarivelojosia M. Efficacy of artesunateamodiaquine for treating uncomplicated falciparum malaria in sub-Saharan Africa: a multi-centre analysis. Malar J 2009, 8:203.

23. Lacaze C, Kauss T, Kiechel JR, Caminiti A, Fawaz F, Terrassin L, Cuart S, Grislain L, Navaratnam V, Ghezzoul B, Gaudin K, White NJ, Olliaro PL, Millet $P$ : The initial pharmaceutical development of an artesunate/amodiaquine oral formulation for the treatment of malaria: a public-private partnership. Malar J 2011, 10:142

24. Nambozi M, van Geertruyden JP, Hachizovu S, Chaponda M, Mukwamataba D, Mulenga M, Ubben D, D'Alessandro U: Safety and efficacy of dihydroartemisininpiperaquine versus artemether-lumefantrine in the treatment of uncomplicated Plasmodium falciparum malaria in Zambian children. Malar J 2011, 10:50.

25. Grande T, Bernasconi A, Erhart A, Gamboa D, Casapia M, Delgado C, Torres K, Fanello C, Llanos-Cuentas A, D'Alessandro U: A randomised controlled trial to assess the efficacy of dihydroartemisinin-piperaquine for the treatment of uncomplicated falciparum malaria in Peru. PLoS One 2007, 2:e1101.

26. Myint HY, Ashley EA, Day NP, Nosten F, White NJ: Efficacy and safety of dihydroartemisinin-piperaquine. Trans R Soc Trop Med Hyg 2007, 101:858-866.

27. Awab GR, Pukrittayakamee S, Imwong M, Dondorp AM, Woodrow CJ, Lee SJ, Day NP, Singhasivanon P, White NJ, Kaker F: Dihydroartemisininpiperaquine versus chloroquine to treat vivax malaria in Afghanistan: an open randomized, non-inferiority, trial. Malar J 2010, 9:105.

28. Bassat $Q$, Mulenga M, Tinto H, Piola P, Borrmann S, Menendez C, Nambozi M, Valea I, Nabasumba C, Sasi P, Bacchieri A, Corsi M, Ubben D, Talisuna A, D'Alessandro U: Dihydroartemisinin-piperaquine and artemetherlumefantrine for treating uncomplicated malaria in African children: a randomised, non-inferiority trial. PLoS One 2009, 4:e7871.

29. Valecha N, Phyo AP, Mayxay M, Newton PN, Krudsood S, Keomany S, Khanthavong M, Pongvongsa T, Ruangveerayuth R, Uthaisil C, Ubben D, Duparc S, Bacchieri A, Corsi M, Rao BH, Bhattacharya PC, Dubhashi N, Ghosh SK Dev V, Kumar A, Pukrittayakamee S: An open-label, randomised study of dihydroartemisinin-piperaquine versus artesunate-mefloquine for falciparum malaria in Asia. PLoS One 2010, 5:e11880.

30. Ramharter M, Kurth F, Schreier AC, Nemeth J, Glasenapp I, Belard S, Schlie M, Kammer J, Koumba PK, Cisse B, Mordmuller B, Lell B, Issifou S, Oeuvray C, Fleckenstein L, Kremsner PG: Fixed-dose pyronaridine-artesunate combination for treatment of uncomplicated falciparum malaria in pediatric patients in Gabon. J Infect Dis 2008, 198:911-919.

31. Price RN, Marfurt J, Chalfein F, Kenangalem E, Piera KA, Tjitra E, Anstey NM, Russell B: In vitro activity of pyronaridine against multidrug-resistant Plasmodium falciparum and Plasmodium vivax. Antimicrob Agents Chemother 2010, 54:5146-5150

32. Poravuth $Y$, Socheat $D$, Rueangweerayut $R$, Uthaisin C, Pyae PA, Valecha N, Rao BH, Tjitra E, Purnama A, Borghini-Fuhrer I, Duparc S, Shin CS, Fleckenstein L: Pyronaridine-artesunate versus chloroquine in patients 
with acute Plasmodium vivax malaria: a randomized, double-blind, noninferiority trial. PLOS One 2011, 6:e14501.

33. Tshefu AK, Gaye O, Kayentao K, Thompson R, Bhatt KM, Sesay SS Bustos DG, Tjitra E, Bedu-Addo G, Borghini-Fuhrer I, Duparc S, Shin CS, Fleckenstein L: Efficacy and safety of a fixed-dose oral combination of pyronaridine-artesunate compared with artemether-lumefantrine in children and adults with uncomplicated Plasmodium falciparum malaria: a randomised non-inferiority trial. Lancet 2010, 375: 1457-1467.

34. Agomo PU, Meremikwu MM, Watila IM, Omalu IJ, Odey FA, Oguche S, Ezeiru VI, Aina OO: Efficacy, safety and tolerability of artesunatemefloquine in the treatment of uncomplicated Plasmodium falciparum malaria in four geographic zones of Nigeria. Malar J 2008, 7:172.

35. Bouyou-Akotet MK, Ramharter M, Ngoungou EB, Mamfoumbi MM, Mihindou MP, Missinou MA, Kurth F, Belard S, Agnandji ST, Issifou S, Heidecker JL, Trapp S, Kremsner PG, Kombila M: Efficacy and safety of a new pediatric artesunate-mefloquine drug formulation for the treatment of uncomplicated falciparum malaria in Gabon. Wien Klin Wochenschr 2010, 122:173-178.

36. Faye B, Ndiaye JL, Tine R, Sylla K, Gueye A, Lo AC, Gaye O: A randomized trial of artesunate mefloquine versus artemether lumefantrine for the treatment of uncomplicated Plasmodium falciparum malaria in Senegalese children. Am J Trop Med Hyg 2010, 82:140-144

37. Schlagenhauf $P$, Adamcova M, Regep L, Schaerer MT, Rhein HG: The position of mefloquine as a 21 st century malaria chemoprophylaxis. Malar J 2010, 9:357.

38. Massougbodji A, Kone M, Kinde-Gazard D, Same-Ekobo A, Cambon N, Mueller EA: A randomized, double-blind study on the efficacy and safety of a practical three-day regimen with artesunate and mefloquine for the treatment of uncomplicated Plasmodium falciparum malaria in Africa. Trans R Soc Trop Med Hyg 2002, 96:655-659.

39. Wang JY, Cao WC, Shan CQ, Zhang M, Li GF, Ding DB, Shi YL, Wu BA: Naphthoquine phosphate and its combination with artemisinine. Acto Trop 2004, 89:375-381.

40. Hombhanje FW, Linge D, Saweri A, Kuanch C, Jones R, Toraso S, Geita J, Masta A, Kevau I, Hiawalyer G, Sapuri M: Artemisinin-naphthoquine combination (ARCO) therapy for uncomplicated falciparum malaria in adults of Papua New Guinea: a preliminary report on safety and efficacy. Malar J 2009, 8:196.

41. Hombhanje FW, Huang Q: Artemisinin-Naphthoquine Combination (ARCO ${ }^{\circledR}$ ): an overview of the progress. Pharmaceuticals 2010, 3:3581-3593.

42. Clinton Foundation Information Center 2012. http://www.clintonfoundation. org/what-we-do/clinton-health-access-initiative/information-centerresources.

43. EMA: Assessment report - Eurartesim (dihydroartemesinin/piperaquine phosphate) 2011. http://www.ema.europa.eu/ema/index.jsp?curl=pages/ medicines/human/orphans/2009/11/human_orphan_000194. jsp\&mid=WC0b01ac058001d12b\&murl=menus/medicines/medicines.jsp.

44. WHO: Guidelines for the Treatment of Malaria 2010. http://www.who.int/ malaria/publications/atoz/9789241547925/en/index.html.

45. Sigma-tau SpA: Application for Inclusion of Dihydroartemisinin Piperaquine (DHA/PPQ) Fixed Dose Combination Tablets in the 17th Edition of the WHO Model Lists of Essential Medicines 2010.

46. MV: New MMV-sponsored antimalarial receives approval from the Korean FDA 2012. http://www.mmv.org/newsroom/news/pyramax\%C2\%AE-edgescloser-patients

47. EMA: Summary of opinion - Pyramax - pyronaridine tetraphosphate/artesunate 2012. http://www.ema.europa.eu/ema/index.jsp?curl=pages/medicines/ document_listing/document_listing_000344.jsp\&mid.

48. DNDi: ASMQ - Fixed-Dose Artesunate/Mefloquine (Malaria) 2010. http://dndi. org/porlfoliolasmq.htrnl?tmpl=component\&print=1\&page

49. Sinclair D, Gogtay N, Brand F: Cochrane Database Syst Rev. In Artemesininbased combination therapy for treating uncomplicated Plasmodium vivax malaria. Edited by Olliaro PL 2011:1-75.

50. About ARCO 2012. http://www.ngcplc.com/arco/index.html.

51. MMV. Coartem Dispersible - 100 million treatments dispatched 2012. http:// www.mmv.org/achievements-challenges/achievements/coartem-d.

52. MMV. Pyramax - Registration process under way 2012. http://www.mmv.org/ research-development/project-portfolio/pyramax\%C2\%AE-pyronaridineartesunate.
53. Folarin OA, Bustamante C, Gbotosho GO, Sowunmi A, Zalis MG, Oduola AM, Happi CT: In vitro amodiaquine resistance and its association with mutations in pfcrt and pfmdr1 genes of Plasmodium falciparum isolates from Nigeria. Acta Trop 2011, 120:224-230.

54. Dondorp AM, Yeung S, White L, Nguon C, Day NP, Socheat D, von SL: Artemisinin resistance: current status and scenarios for containment. Nat Rev Microbiol 2010, 8:272-280.

55. Rueangweerayut $R$, Phyo AP, Uthaisin C, Poravuth $Y$, Binh TQ, Tinto H, Penali LK, Valecha N, Tien NT, Abdulla S, Borghini-Fuhrer I, Duparc S, Shin CS, Fleckenstein L: Pyronaridine-artesunate versus mefloquine plus artesunate for malaria. $N$ Engl J Med 2012, 366:1298-1309.

56. Phyo AP, Nkhoma S, Stepniewska K, Ashley EA, Nair S, McGready R, Ler MC, AlSaai S, Dondorp AM, Lwin KM, Singhasivanon P, Day NP, White NJ, Anderson TJ, Nosten F: Emergence of artemisinin-resistant malaria on the western border of Thailand: a longitudinal study. Lancet 2012, 379:1960-1966.

57. Boni MF, Smith DL, Laxminarayan R: Benefits of using multiple first-line therapies against malaria. Proc Natl Acad Sci USA 2008, 105:14216-14221.

58. Wells TN, Poll EM: When is enough enough? The need for a robust pipeline of high-quality antimalarials. Discov Med 2010, 9:389-398.

59. ClinicalTrials.gov 2012. www. clinicaltrials.gov.

60. MMV Medicines for Malaria Venture 2012. www.mmv.org

61. Dondorp AM, Fanello Cl, Hendriksen IC, Gomes E, Seni A, Chhaganlal KD, Bojang K, Olaosebikan R, Anunobi N, Maitland K, Kivaya E, Agbenyega T, Nguah SB, Evans J, Gesase S, Kahabuka C, Mtove G, Nadjm B, Deen J, MwangaAmumpaire J, Nansumba M, Karema C, Umulisa N, Uwimana A, Mokuolu OA Adedoyin OT, Johnson WB, Tshefu AK, Onyamboko MA, Sakulthaew T, Ngum WP, Silamut K, Stepniewska K, Woodrow CJ, Bethell D, Wills B, Oneko M, Peto $T E$, Von SL, Day NP, White NJ: Artesunate versus quinine in the treatment of severe falciparum malaria in African children (AQUAMAT): an open-label, randomised trial. Lancet 2010, 376:1647-1657.

62. Li Q, Weina P: Artesunate: The Best Drug in the Treatment of Severe and Complicated Malaria. Pharmaceuticals 2010, 3:2322-2332.

63. Dondorp A, Nosten F, Stepniewska K, Day N, White N: Artesunate versus quinine for treatment of severe falciparum malaria: a randomised trial. Lancet 2005, 366:717-725.

64. Lubell Y, Yeung S, Dondorp AM, Day NP, Nosten F, Tjitra E, Abul FM, Yunus EB, Anstey NM, Mishra SK, Mohanty S, White NJ, Mills AJ: Cost-effectiveness of artesunate for the treatment of severe malaria. Trop Med Int Health 2009, 14:332-337.

65. Tozan Y, Klein EY, Darley S, Panicker R, Laxminarayan R, Breman JG: Prereferral rectal artesunate for treatment of severe childhood malaria: $\mathrm{a}$ cost-effectiveness analysis. Lancet 2010, 376:1910-1915.

66. Gomes MF, Faiz MA, Gyapong JO, Warsame M, Agbenyega T, Babiker A, Baiden F, Yunus EB, Binka F, Clerk C, Folb P, Hassan R, Hossain MA, Kimbute O, Kitua A, Krishna S, Makasi C, Mensah N, Mrango Z, Olliaro P, Peto R, Peto TJ, Rahman MR, Ribeiro I, Samad R, White NJ: Pre-referral rectal artesunate to prevent death and disability in severe malaria: a placebo-controlled trial. Lancet 2009, 373:557-566

67. Gomes M, Ribeiro I, Warsame M, Karunajeewa H, Petzold M: Rectal artemisinins for malaria: a review of efficacy and safety from individual patient data in clinical studies. BMC Infect Dis 2008, 8:39.

68. Doumbo OK, Thera MA, Kone AK, Raza A, Tempest LJ, Lyke KE, Plowe CV, Rowe JA: High levels of Plasmodium falciparum rosetting in all clinical forms of severe malaria in African children. Am J Trop Med Hyg 2009, 81:987-993.

69. Rosenthal PJ: Artesunate for the treatment of severe falciparum malaria N Engl J Med 2008, 358:1829-1836.

70. Afolabi BB, Okoromah CN: Intramuscular artemether for treating severe malaria. Cochrane Database Syst Rev 2004, CD004391.

71. Taudon N, Margout D, Wein S, Calas M, Vial HJ, Bressolle FM: Quantitative analysis of a bis-thiazolium antimalarial compound, SAR97276, in mouse plasma and red blood cell samples, using liquid chromatography mass spectrometry. J Pharm Biomed Anal 2008, 46:148-156.

72. Ohrt C, Willingmyre GD, Lee $P$, Knirsch C, Milhous W: Assessment of azithromycin in combination with other antimalarial drugs against Plasmodium falciparum in vitro. Antimicrob Agents Chemother 2002, 46:2518-2524.

73. Pereira MR, Henrich PP, Sidhu AB, Johnson D, Hardink J, Van DJ, Lin J, Gore K, O'Brien C, Wele M, Djimde A, Chandra R, Fidock DA: In vivo and in vitro antimalarial properties of azithromycin-chloroquine combinations that include the resistance reversal agent amlodipine. Antimicrob Agents Chemother 2011, 55:3115-3124. 
74. Noedl H, Krudsood S, Chalermratana K, Silachamroon U, Leowattana W, Tangpukdee N, Looareesuwan S, Miller RS, Fukuda M, Jongsakul K, Sriwichai S, Rowan J, Bhattacharyya H, Ohrt C, Knirsch C: Azithromycin combination therapy with artesunate or quinine for the treatment of uncomplicated Plasmodium falciparum malaria in adults: a randomized, phase 2 clinical trial in Thailand. Clin Infect Dis 2006, 43:1264-1271.

75. Dunne MW, Singh N, Shukla M, Valecha N, Bhattacharyya PC, Dev V, Patel K, Mohapatra MK, Lakhani J, Benner R, Lele C, Patki K: A multicenter study of azithromycin, alone and in combination with chloroquine, for the treatment of acute uncomplicated Plasmodium falciparum malaria in India. J Infect Dis 2005, 191:1582-1588.

76. Geraghty EM: Plasmodium fulciparum infection in a patient receiving infliximab therapy for rheumatoid arthritis. Clin Infect Dis 2007, 72:46-e84.

77. Fehintola FA, Balogun ST: Comparative study of efficacy of artesunate plus cotrimoxazole and artesunate plus chloroquine in the treatment of malaria in Nigerian children: a preliminary report. J Vector Borne Dis 2010, 47:145-150.

78. Fehintola FA, Adedeji AA, Gbotosho GO, Happi CT, Balogun ST, Folarin OA, Sijuade $\mathrm{AO}$, Sowunmi A: Effects of artesunate-cotrimoxazole and amodiaquine-artesunate against asexual and sexual stages of Plasmodium falciparum malaria in Nigerian children. J Infect Chemother 2008, 14:188-194.

79. Graz B, Dicko M, Willcox ML, Lambert B, Falquet J, Forster M, Giani S, Diakite C, Dembele EM, Diallo D, Barennes H: Sublingual sugar for hypoglycaemia in children with severe malaria: a pilot clinical study. Malar J 2008, 7:242.

80. Hamel MJ, Holtz T, Mkandala C, Kaimila N, Chizani N, Bloland P, Kublin J, Kazembe P, Steketee R: Efficacy of trimethoprim-sulfamethoxazole compared with sulfadoxine-pyrimethamine plus erythromycin for the treatment of uncomplicated malaria in children with integrated management of childhood illness dual classifications of malaria and pneumonia. Am J Trop Med Hyg 2005, 73:609-615.

81. Fugi MA, Wittlin S, Dong $Y$, Vennerstrom JL: Probing the antimalarial mechanism of artemisinin and OZ277 (arterolane) with nonperoxidic isosteres and nitroxyl radicals. Antimicrob Agents Chemother 2010, 54:1042-1046.

82. Maerki S, Brun R, Charman SA, Dorn A, Matile H, Wittlin S: In vitro assessment of the pharmacodynamic properties and the partitioning of OZ277/RBX-11160 in cultures of Plasmodium falciparum. J Antimicrob Chemother 2006, 58:52-58.

83. Uhlemann AC, Wittlin S, Matile H, Bustamante LY, Krishna S: Mechanism of antimalarial action of the synthetic trioxolane RBX11160 (OZ277) Antimicrob Agents Chemother 2007, 51:667-672.

84. Charman SA, Arbe-Barnes S, Bathurst IC, Brun R, Campbell M, Charman WN, Chiu FC, Chollet J, Craft JC, Creek DJ, Dong Y, Matile H, Maurer M, Morizzi J, Nguyen T, Papastogiannidis P, Scheurer C, Shackleford DM, Sriraghavan K, Stingelin L, Tang Y, Urwyler H, Wang X, White KL, Wittlin S, Zhou L, Vennerstrom JL: Synthetic ozonide drug candidate OZ439 offers new hope for a single-dose cure of uncomplicated malaria. Proc Natl Acad SCi USA 2011, 108:4400-4405.

85. Kreidenweiss A, Mordmuller B, Krishna S, Kremsner PG: Antimalarial activity of a synthetic endoperoxide (RBx-11160/OZ277) against Plasmodium falciparum isolates from Gabon. Antimicrob Agents Chemother 2006, 50:1535-1537.

86. Dong Y, Wittlin S, Sriraghavan K, Chollet J, Charman SA, Charman WN, Scheurer C, Urwyler H, Santo TJ, Snyder C, Creek DJ, Morizzi J, Koltun M, Matile H, Wang X, Padmanilayam M, Tang Y, Dorn A, Brun R, Vennerstrom $J$ : The structure-activity relationship of the antimalarial ozonide arterolane (OZ277). J Med Chem 2010, 53:481-491.

87. Daher W, Pelinski L, Klieber S, Sadoun F, Meunier V, Bourrie M, Biot C, Guillou F, Fabre G, Brocard J, Fraisse L, Maffrand JP, Khalife J, Dive D: In vitro metabolism of ferroquine (SSR97193) in animal and human hepatic models and antimalarial activity of major metabolites on Plasmodium falciparum. Drug Metab Dispos 2006, 34:667-682

88. Mombo-Ngoma G, Supan C, Dal-Bianco MP, Missinou MA, Matsiegui PB, Ospina Salazar CL, Issifou S, Ter-Minassian D, Ramharter M, Kombila M, Kremsner PG, Lell B: Phase I randomized dose-ascending placebocontrolled trials of ferroquine-a candidate anti-malarial drug-in adults with asymptomatic Plasmodium falciparum infection. Malar $J$ 2011, 10:53.

89. Leimanis ML, Jaidee A, Sriprawat $K$, Kaewpongsri S, Suwanarusk R, Barends M, Phyo AP, Russell B, Renia L, Nosten F: Plasmodium vivax susceptibility to ferroquine. Antimicrob Agents Chemother 2010, 54:2228-2230.
90. Dubar F, Khalife J, Brocard J, Dive D, Biot C: Ferroquine, an ingenious antimalarial drug: thoughts on the mechanism of action. Molecules 2008 , 13:2900-2907.

91. Barends M, Jaidee A, Khaohirun N, Singhasivanon P, Nosten F: In vitro activity of ferroquine (SSR 97193) against Plasmodium falciparum isolates from the Thai-Burmese border. Malar J 2007, 6:81.

92. Ruangweerayut R, Looareesuwan S, Hutchinson D, Chauemung A, Banmairuroi V, $\mathrm{Na}$-Bangchang $\mathrm{K}$ : Assessment of the pharmacokinetics and dynamics of two combination regimens of fosmidomycin-clindamycin in patients with acute uncomplicated falciparum malaria. Malar J 2008, 7:225.

93. Oyakhirome S, Issifou S, Pongratz P, Barondi F, Ramharter M, Kun JF Missinou MA, Lell B, Kremsner PG: Randomized controlled trial of fosmidomycin-clindamycin versus sulfadoxine-pyrimethamine in the treatment of Plasmodium falciparum malaria. Antimicrob Agents Chemother 2007, 51:1869-1871.

94. Tomonubu U, Nobutada T, Yoshio K, Masayuki N, Yukio K, Kazuo KT: Molecular basis of fosmidomycin's action on the human malaria parasite Plasmodium falciparum. Sci Rep 2011, 1:1-8.

95. Wiesner J, Henschker D, Hutchinson DB, Beck E, Jomaa H: In vitro and in vivo synergy of fosmidomycin, a novel antimalarial drug, with clindamycin. Antimicrob Agents Chemother 2002, 46:2889-2894.

96. Na-Bangchang K, Ruengweerayut R, Karbwang J, Chauemung A, Hutchinson D: Pharmacokinetics and pharmacodynamics of fosmidomycin monotherapy and combination therapy with clindamycin in the treatment of multidrug resistant falciparum malaria. Malar J 2007, 6:70.

97. Rengelshausen J, Burhenne J, Frohlich M, Tayrouz Y, Singh SK, Riedel KD, Muller O, Hoppe-Tichy T, Haefeli WE, Mikus G, Walter-Sack I: Pharmacokinetic interaction of chloroquine and methylene blue combination against malaria. Eur J Clin Pharmacol 2004, 60:709-715.

98. Meissner PE, Mandi G, Coulibaly B, Witte S, Tapsoba T, Mansmann U, Rengelshausen J, Schiek W, Jahn A, Walter-Sack I, Mikus G, Burhenne J, Riedel KD, Schirmer RH, Kouyate B, Muller O: Methylene blue for malaria in Africa: results from a dose-finding study in combination with chloroquine. Malar J 2006, $5: 84$

99. Akoachere M, Buchholz K, Fischer E, Burhenne J, Haefeli WE, Schirmer RH, Becker K: In vitro assessment of methylene blue on chloroquine-sensitive and -resistant Plasmodium falciparum strains reveals synergistic action with artemisinins. Antimicrob Agents Chemother 2005, 49:4592-4597.

100. Yeung BK, Zou B, Rottmann M, Lakshminarayana SB, Ang SH, Leong SY, Tan J, Wong J, Keller-Maerki S, Fischli C, Goh A, Schmitt EK, Krastel P, Francotte E, Kuhen K, Plouffe D, Henson K, Wagner T, Winzeler EA, Petersen F, Brun R, Dartois $V$, Diagana TT, Keller TH: Spirotetrahydro beta-carbolines (spiroindolones): a new class of potent and orally efficacious compounds for the treatment of malaria. J Med Chem 2010, 53:5155-5164.

101. Rottmann M, McNamara C, Yeung BK, Lee MC, Zou B, Russell B, Seitz P, Plouffe DM, Dharia NV, Tan J, Cohen SB, Spencer KR, Gonzalez-Paez GE, Lakshminarayana SB, Goh A, Suwanarusk R, Jegla T, Schmitt EK, Beck HP, Brun R, Nosten F, Renia L, Dartois V, Keller TH, Fidock DA, Winzeler EA, Diagana TT: Spiroindolones, a potent compound class for the treatment of malaria. Science 2010, 329:1175-1180.

102. Skerlj RT, Bastos CM, Booker ML, Kramer ML, Barker RH, Celatka CA, O'Shea TJ, Munoz B, Sidhu AB, Cortese JF, Wittlin S, Papastogiannidis P, Angulo-Barturen I, Jimenez-Diaz MB, Sybertz E: Optimization of Potent Inhibitors of $P$. falciparum Dihydroorotate Dehydrogenase for the Treatment of Malaria. A C S Med Chem Lett 2011, 2:708-713.

103. Phillips MA, Rathod PK: Plasmodium dihydroorotate dehydrogenase: a promising target for novel anti-malarial chemotherapy. Infect Disord Drug Targets 2010, 10:226-239.

104. Gujjar R, Marwaha A, El MF, White J, White KL, Creason S, Shackleford DM, Baldwin J, Charman WN, Buckner FS, Charman S, Rathod PK, Phillips MA: Identification of a metabolically stable triazolopyrimidine-based dihydroorotate dehydrogenase inhibitor with antimalarial activity in mice. J Med Chem 2009, 52:1864-1872.

105. Desai KR, Shaikh M, Coutinho EC: Molecular modeling studies, synthesis and biological evaluation of derivatives of $\mathrm{N}$-Phenylbenzamide as Plasmodium falciparum dihyroorotate dehydrogenase (PfDHODH) inhibitors. Medicinal Chemistry Research 2010, 20:321-332.

106. Barker RH Jr, Urgaonkar S, Mazitschek R, Celatka C, Skerlj R, Cortese JF, Tyndall E, Liu H, Cromwell M, Sidhu AB, Guerrero-Bravo JE, Crespo-Llado KN, Serrano AE, Lin JW, Janse CJ, Khan SM, Duraisingh M, Coleman BI, Angulo- 
Barturen I, Jimenez-Diaz MB, Magan N, Gomez V, Ferrer S, Martinez MS, Wittlin S, Papastogiannidis P, O'Shea T, Klinger JD, Bree M, Lee E, Levine M, Wiegand RC, Munoz B, Wirth DF, Clardy J, Bathurst I, Sybertz E: Aminoindoles, a novel scaffold with potent activity against Plasmodium falciparum. Antimicrob Agents Chemother 2011, 55:2612-2622

107. O'Neill PM, Amewu RK, Nixon GL, Bousejra EF, Mungthin M, Chadwick J, Shone AE, Vivas L, Lander H, Barton V, Muangnoicharoen S, Bray PG, Davies J, Park BK, Wittlin S, Brun R, Preschel M, Zhang K, Ward SA: Identification of a 1,2,4,5-tetraoxane antimalarial drug-development candidate (RKA 182) with superior properties to the semisynthetic artemisinins. Angew Chem Int Ed Engl 2010, 49:5693-5697.

108. Solaja BA, Terzic N, Pocsfalvi G, Gerena L, Tinant B, Opsenica D, Milhous WK: Mixed steroidal 1,2,4,5-tetraoxanes: antimalarial and antimycobacterial activity. J Med Chem 2002, 45:3331-3336.

109. Shi W, Ting LM, Kicska GA, Lewandowicz A, Tyler PC, Evans GB, Furneaux $\mathrm{RH}$, Kim K, Almo SC, Schramm VL: Plasmodium falciparum purine nucleoside phosphorylase: crystal structures, immucillin inhibitors, and dual catalytic function. J Biol Chem 2004, 279:18103-18106.

110. Madrid DC, Ting LM, Waller KL, Schramm VL, Kim K: Plasmodium falciparum purine nucleoside phosphorylase is critical for viability of malaria parasites. J Biol Chem 2008, 283:35899-35907.

111. Singh C, Chaudhary S, Kanchan R, Puri SK: Conversion of antimalarial drug artemisinin to a new series of tricyclic 1,2,4-trioxanes1. Org Lett 2007, 9:4327-4329.

112. Riccio ES, Lee PS, Winegar RA, Krogstad DJ, De D, Mirsalis JC: Genetic toxicology testing of the antimalarial drugs chloroquine and a new analog, AQ-13. Environ Mol Mutagen 2001, 38:69-79.

113. Mzayek F, Deng H, Mather FJ, Wasilevich EC, Liu H, Hadi CM, Chansolme DH, Murphy HA, Melek BH, Tenaglia AN, Mushatt DM, Dreisbach AW, Lertora J, Krogstad DJ: Randomized dose-ranging controlled trial of AQ-13, a candidate antimalarial, and chloroquine in healthy volunteers. PLoS Clin Trials 2007, 2:e6

114. O'Neill PM, Shone AE, Stanford D, Nixon G, Asadollahy E, Park BK, Maggs JL, Roberts P, Stocks PA, Biagini G, Bray PG, Davies J, Berry N, Hall C, Rimmer K, Winstanley PA, Hindley S, Bambal RB, Davis CB, Bates M, Gresham SL, Brigandi RA, Gomez-de-Las-Heras FM, Gargallo DV, Parapini S, Vivas L, Lander H, Taramelli D, Ward SA: Synthesis, antimalarial activity, and preclinical pharmacology of a novel series of 4'-fluoro and 4'-chloro analogues of amodiaquine. Identification of a suitable "back-up" compound for N-tert-butyl isoquine. J Med Chem 2009, 52:1828-1844.

115. Bora S, Chetia D, Prakash A: Synthesis and antimalarial activity evaluation of some isoquine analogues. Med Chem Res 2011, 20:1632-1637.

116. O'Neill PM, Park BK, Shone AE, Maggs JL, Roberts P, Stocks PA, Biagini GA, Bray PG, Gibbons P, Berry N, Winstanley PA, Mukhtar A, Bonar-Law R, Hindley S, Bambal RB, Davis CB, Bates M, Hart TK, Gresham SL, Lawrence RM, Brigandi RA, Gomez-delas-Heras FM, Gargallo DV, Ward SA: Candidate selection and preclinical evaluation of N-tert-butyl isoquine (GSK369796), an affordable and effective 4-aminoquinoline antimalarial for the 21st century. J Med Chem 2009, 52:1408-1415.

117. Lawrence RM, Dennis KC, O'Neill PM, Hahn DU, Roeder M, Struppe C: Development of a Scalable Synthetic Route to GSK369796 (N-tert-Butyl Isoquine), a Novel 4-Aminoquinoline Antimalarial Drug. Org Process Res Dev 2008, 12:294-297.

118. Cosledan F, Fraisse L, Pellet A, Guillou F, Mordmuller B, Kremsner PG, Moreno A, Mazier D, Maffrand JP, Meunier B: Selection of a trioxaquine as an antimalarial drug candidate. Proc Nat/ Acad Sci USA 2008, 105:17579-17584.

119. Waknine-Grinberg JH, Hunt N, Bentura-Marciano A, McQuillan JA, Chan HW, Chan WC, Barenholz Y, Haynes RK, Golenser J: Artemisone effective against murine cerebral malaria. Malar J 2010, 9:227.

120. Pooley S, Fatih FA, Krishna S, Gerisch M, Haynes RK, Wong HN, Staines HM: Artemisone uptake in Plasmodium falciparum-infected erythrocytes. Antimicrob Agents Chemother 2011, 55:550-556.

121. Vivas L, Rattray L, Stewart LB, Robinson BL, Fugmann B, Haynes RK, Peters W, Croft SL: Antimalarial efficacy and drug interactions of the novel semisynthetic endoperoxide artemisone in vitro and in vivo. J Antimicrob Chemother 2007, 59:658-665

122. Nagelschmitz J, Voith B, Wensing G, Roemer A, Fugmann B, Haynes RK, Kotecka BM, Rieckmann KH, Edstein MD: First assessment in humans of the safety, tolerability, pharmacokinetics, and ex vivo pharmacodynamic antimalarial activity of the new artemisinin derivative artemisone. Antimicrob Agents Chemother 2008, 52:3085-3091.
123. Charunwatthana P, Abul FM, Ruangveerayut R, Maude RJ, Rahman MR, Roberts LJ, Moore K, Bin YE, Hoque MG, Hasan MU, Lee SJ,

Pukrittayakamee S, Newton PN, White NJ, Day NP, Dondorp AM: $\mathrm{N}$-acetylcysteine as adjunctive treatment in severe malaria: a randomized, double-blinded placebo-controlled clinical trial. Crit Care Med 2009, 37:516-522.

124. Lell B, Kohler C, Wamola B, Olola CH, Kivaya E, Kokwaro G, Wypij D, Mithwani S, Taylor TE, Kremsner PG, Newton CR: Pentoxifylline as an adjunct therapy in children with cerebral malaria. Malar J 2010, 9:368.

125. Lamphier MS, Sirois CM, Verma A, Golenbock DT, Latz E: TLR9 and the recognition of self and non-self nucleic acids. Ann N Y Acad Sci 2006 1082:31-43.

126. Parroche P, Lauw FN, Goutagny N, Latz E, Monks BG, Visintin A, Halmen KA Lamphier M, Olivier M, Bartholomeu DC, Gazzinelli RT, Golenbock DT: Malaria hemozoin is immunologically inert but radically enhances innate responses by presenting malaria DNA to Toll-like receptor 9. Proc Nat/ Acad Sci USA 2007, 104:1919-1924.

127. Ben MC, Prigge ST, Vial H: Targeting the Lipid Metabolic Pathways for the Treatment of Malaria. Drug Dev Res 2010, 71:44-55.

128. White NJ, Turner GD, Medana IM, Dondorp AM, Day NP: The murine cerebral malaria phenomenon. Trends Parasitol 2010, 26:11-15.

129. Marsh K: Artemesinins for severe malaria in Africa. East Afr Med J 2002, 79:619-620.

130. Brewer TG, Peggins JO, Grate SJ, Petras JM, Levine BS, Weina PJ, Swearengen J, Heiffer MH, Schuster BG: Neurotoxicity in animals due to arteether and artemether. Trans R Soc Trop Med Hyg 1994, 88(Suppl 1):S33-S36.

131. McGready R, Nosten F: Which drug is effective and safe for acute malaria in pregnancy? Drug Dev Res 2009, 71:56-68.

132. Nosten F, McGready R, Mutabingwa T: Case management of malaria in pregnancy. Lancet Infect Dis 2007, 7:118-125.

133. McGready R, Stepniewska K, Lindegardh N, Ashley EA, La Y, Singhasivanon $P$, White NJ, Nosten F: The pharmacokinetics of artemether and lumefantrine in pregnant women with uncomplicated falciparum malaria. Eur J Clin Pharmacol 2006, 62:1021-1031.

134. Chico RM, Pittrof R, Greenwood B, Chandramohan D: Azithromycinchloroquine and the intermittent preventive treatment of malaria in pregnancy. Malar J 2008, 7:255

135. Briand V, Bottero J, Noel H, Masse V, Cordel H, Guerra J, Kossou H, Fayomi B, Ayemonna P, Fievet N, Massougbodji A, Cot M: Intermittent treatment for the prevention of malaria during pregnancy in Benin: a randomized, open-label equivalence trial comparing sulfadoxine-pyrimethamine with mefloquine. J Infect Dis 2009, 200:991-1001.

136. Tansley R, Lotharius J, Priestley A, Bull F, Duparc S, Mohrle J: A randomized, double-blind, placebo-controlled study to investigate the safety, tolerability, and pharmacokinetics of single enantiomer (+)-mefloquine compared with racemic mefloquine in healthy persons. Am J Trop Med Hyg 2010, 83:1195-1201.

137. Graham IA, Besser K, Blumer S, Branigan CA, Czechowski T, Elias L, Guterman I, Harvey D, Isaac PG, Khan AM, Larson TR, Li Y, Pawson T, Penfield T, Rae AM, Rathbone DA, Reid S, Ross J, Smallwood MF, Segura V, Townsend T, Vyas D, Winzer T, Bowles D: The genetic map of Artemisia annua L. identifies loci affecting yield of the antimalarial drug artemisinin. Science 2010, 327:328-331.

138. Tsuruta H, Paddon CJ, Eng D, Lenihan JR, Horning T, Anthony LC, Regentin R, Keasling JD, Renninger NS, Newman JD: High-level production of amorpha-4,11-diene, a precursor of the antimalarial agent artemisinin, in Escherichia coli. PLoS One 2009, 4:e4489.

139. Valecha N, Looareesuwan S, Martensson A, Abdulla SM, Krudsood S, Tangpukdee N, Mohanty S, Mishra SK, Tyagi PK, Sharma SK, Moehrle J, Gautam A, Roy A, Paliwal JK, Kothari M, Saha N, Dash AP, Bjorkman A: Arterolane, a new synthetic trioxolane for treatment of uncomplicated Plasmodium falciparum malaria: a phase II, multicenter, randomized, dose-finding clinical trial. Clin Infect Dis 2010, 51:684-691.

140. Briolant $\mathrm{S}$, Henry M, Oeuvray C, Amalvict R, Baret E, Didillon E, Rogier C, Pradines $B$ : Absence of association between piperaquine in vitro responses and polymorphisms in the pfcrt, pfmdr1, pfmrp, and pfnhe genes in Plasmodium falciparum. Antimicrob Agents Chemother 2012, 54:3537-3544.

141. Mishra S, Manickavasagam L, Jain GK: Determination of metabolic profile of anti-malarial trioxane CDRI 99/411 in rat liver microsomes using HPLC. Biomed Chromatogr 2012, 26:115-122 
142. Vennerstrom JL, Nuzum EO, Miller RE, Dorn A, Gerena L, Dande PA, Ellis WY, Ridley RG, Milhous WK: 8-Aminoquinolines active against blood stage Plasmodium falciparum in vitro inhibit hematin polymerization. Antimicrob Agents Chemother 1999, 43:598-602.

143. Lell B, Faucher JF, Missinou MA, Borrmann S, Dangelmaier O, Horton J, Kremsner PG: Malaria chemoprophylaxis with tafenoquine: a randomised study. Lancet 2000, 355:2041-2045.

144. Brueckner RP, Lasseter KC, Lin ET, Schuster BG: First-time-in-humans safety and pharmacokinetics of WR 238605, a new antimalarial. Am J Trop Med Hyg 1998, 58:645-649.

145. Nasveld $P$, Kitchener $S$ : Treatment of acute vivax malaria with tafenoquine. Trans R Soc Trop Med Hyg 2005, 99:2-5.

146. Elmes NJ, Nasveld PE, Kitchener SJ, Kocisko DA, Edstein MD: The efficacy and tolerability of three different regimens of tafenoquine versus primaquine for post-exposure prophylaxis of Plasmodium vivax malaria in the Southwest Pacific. Trans R Soc Trop Med Hyg 2008, 102:1095-1101.

147. Nanayakkara NP, Ager AL Jr, Bartlett MS, Yardley V, Croft SL, Khan IA, McChesney JD, Walker LA: Antiparasitic activities and toxicities of individual enantiomers of the 8-aminoquinoline 8-[(4-amino-1methylbutyl)amino]-6-methoxy-4-methyl-5-[3,4-dichlorophenoxy] quinoline succinate. Antimicrob Agents Chemother 2008, 52:2130-2137.

148. Delves M, Plouffe D, Scheurer C, Meister S, Wittlin S, Winzeler EA, Sinden RE, Leroy D: The activities of current antimalarial drugs on the life cycle stages of Plasmodium: a comparative study with human and rodent parasites. PLoS Med 2012, 9:e1001169.

149. Lell B, Ruangweerayut R, Wiesner J, Missinou MA, Schindler A, Baranek T, Hintz M, Hutchinson D, Jomaa H, Kremsner PG: Fosmidomycin, a novel chemotherapeutic agent for malaria. Antimicrob Agents Chemother 2003, 47:735-738

150. Andriantsoanirina V, Durand R, Pradines B, Baret E, Bouchier C, Ratsimbasoa A, Menard D: In vitro susceptibility to pyrimethamine of DHFR I164L single mutant Plasmodium falciparum. Malar J 2011, 10:283.

151. Payne DJ, Gwynn MN, Holmes DJ, Pompliano DL: Drugs for bad bugs: confronting the challenges of antibacterial discovery. Nat Rev Drug Discov 2007, 6:29-40

152. Guiguemde WA, Shelat AA, Bouck D, Duffy S, Crowther GJ, Davis PH, Smithson DC, Connelly M, Clark J, Zhu F, Jimenez-Diaz MB, Martinez MS, Wilson EB, Tripathi AK, Gut J, Sharlow ER, Bathurst I, El MF, Fowble JW, Forquer I, McGinley PL, Castro S, Angulo-Barturen I, Ferrer S, Rosenthal PJ, Derisi JL, Sullivan DJ, Lazo JS, Roos DS, Riscoe MK, Phillips MA, Rathod PK, Van Voorhis WC, Avery VM, Guy RK: Chemical genetics of Plasmodium falciparum. Nature 2010, 465:311-315

153. Gamo FJ, Sanz LM, Vidal J, De CC, Alvarez E, Lavandera JL, Vanderwall DE, Green DV, Kumar V, Hasan S, Brown JR, Peishoff CE, Cardon LR, GarciaBustos JF: Thousands of chemical starting points for antimalarial lead identification. Nature 2010, 465:305-310.

154. Plouffe D, Brinker A, McNamara C, Henson K, Kato N, Kuhen K, Nagle A, Adrian F, Matzen JT, Anderson P, Nam TG, Gray NS, Chatterjee A, Janes J, Yan SF, Trager R, Caldwell JS, Schultz PG, Zhou Y, Winzeler EA: In silico activity profiling reveals the mechanism of action of antimalarials discovered in a high-throughput screen. Proc Natl Acad Sci USA 2008, 105:9059-9064.

155. Krishna S, Woodrow C, Webb R, Penny J, Takeyasu K, Kimura M, East JM: Expression and functional characterization of a Plasmodium falciparum Ca2 + -ATPase (PfATP4) belonging to a subclass unique to apicomplexan organisms. J Biol Chem 2001, 276:10782-10787.

156. Meister S, Plouffe DM, Kuhen KL, Bonamy GM, Wu T, Barnes SW, Bopp SE, Borboa R, Bright AT, Che J, Cohen S, Dharia NV, Gagaring K, Gettayacamin M, Gordon P, Groessl T, Kato N, Lee MC, McNamara CW, Fidock DA, Nagle A, Nam TG, Richmond W, Roland J, Rottmann M, Zhou B, Froissard P, Glynne RJ, Mazier D, Sattabongkot J, Schultz PG, Tuntland T, Walker JR, Zhou Y, Chatterjee A, Diagana T, Winzeler EA: Imaging of Plasmodium liver stages to drive next-generation antimalarial drug discovery. Science 2011, 334:1372-1377.

157. Lei $\mathrm{SH}$ : From Changshan to a new anti-malarial drug: re-networking Chinese drugs and excluding Chinese doctors. Soc Stud Sci 1999, 29:323.

158. Wells TN: Natural products as starting points for future anti-malarial therapies: going back to our roots? Malar J 2011, 10(Suppl1):S3.

159. Ginsburg $H$, Deharo E: A call for using natural compounds in the development of new antimalarial treatments - an introduction. Malar J 2011, 10(Suppl 1):S1.
160. Willcox ML, Graz B, Falquet J, Diakite C, Giani S, Diallo D: A "reverse pharmacology" approach for developing an anti-malarial phytomedicine. Malar J 2011, 10(Suppl 1):S8.

161. Mesia K, Cimanga RK, Dhooghe L, Cos P, Apers S, Totte J, Tona GL, et al: Antimalarial activity and toxicity evaluation of a quantified Nauclea pobeguinii extract. J Ethnopharmacol 2010, 131:10-16.

162. Graz B, Willcox ML, Diakite C, Falquet J, Dackuo F, Sidibe O, Giani S, Diallo D: Argemone mexicana decoction versus artesunate-amodiaquine for the management of malaria in Mali: policy and public-health implications. Trans R Soc Trop Med Hyg 2010, 104:33-41.

163. Dembele L, Gego A, Zeeman AM, Franetich JF, Silvie O, Rametti A, Le GR, Dereuddre-Bosquet N, Sauerwein R, van Gemert GJ, Vaillant JC, Thomas AW, Snounou G, Kocken $\mathrm{CH}$, Mazier D: Towards an in vitro model of Plasmodium hypnozoites suitable for drug discovery. PLoS One 2011, 6:e18162.

164. Sacarlal J, Aide P, Aponte JJ, Renom M, Leach A, Mandomando I, Lievens M, Bassat Q, Lafuente S, Macete E, Vekemans J, Guinovart C, Sigauque B, Sillman M, Milman J, Dubois MC, Demoitie MA, Thonnard J, Menendez C, Ballou WR, Cohen J, Alonso PL: Long-term safety and efficacy of the RTS, S/AS02A malaria vaccine in Mozambican children. J Infect Dis 2009, 200:329-336.

165. Kester KE, Cummings JF, Ofori-Anyinam O, Ockenhouse CF, Krzych U, Moris P, Schwenk R, Nielsen RA, Debebe Z, Pinelis E, Juompan L, Williams J, Dowler M, Stewart VA, Wirtz RA, Dubois MC, Lievens M, Cohen J, Ballou WR, Heppner DG Jr: Randomized, double-blind, phase 2a trial of falciparum malaria vaccines RTS, S/AS01B and RTS, S/AS02A in malaria-naive adults: safety, efficacy, and immunologic associates of protection. J Infect Dis 2009, 200:337-346.

166. Bejon $\mathrm{P}$, Lusingu J, Olotu A, Leach A, Lievens M, Vekemans J, Mshamu S, Lang T, Gould J, Dubois MC, Demoitie MA, Stallaert JF, Vansadia P, Carter T, Njuguna P, Awuondo KO, Malabeja A, Abdul O, Gesase S, Mturi N, Drakeley CJ, Savarese B, Villafana T, Ballou WR, Cohen J, Riley EM, Lemnge MM, Marsh K, Von SL: Efficacy of RTS, S/AS01E vaccine against malaria in children 5 to 17 months of age. N Engl J Med 2008, 359:2521-2532.

167. Olliaro P, Wells TN: The global portfolio of new antimalarial medicines under development. Clin Pharmacol Ther 2009, 85:584-595.

doi:10.1186/1475-2875-11-316

Cite this article as: Anthony et al:: The global pipeline of new medicines for the control and elimination of malaria. Malaria Journal 2012 11:316.

\section{Submit your next manuscript to BioMed Central and take full advantage of:}

- Convenient online submission

- Thorough peer review

- No space constraints or color figure charges

- Immediate publication on acceptance

- Inclusion in PubMed, CAS, Scopus and Google Scholar

- Research which is freely available for redistribution

Submit your manuscript at www.biomedcentral.com/submit
C BioMed Central 